\title{
Avian egg size: variation within species and inflexibility within individuals
}

\author{
JULIAN K. CHRISTIANS* \\ Department of Biological Sciences, Simon Fraser University, Burnaby, British Columbia, V5A 1S6, Canada
}

(Received 3 November 2000; revised 24 Fuly 2001; accepted 24 Fuly 2001)

\begin{abstract}
Egg size is a widely-studied trait and yet the causes and consequences of variation in this trait remain poorly understood. Egg size varies greatly within many avian species, with the largest egg in a population generally being at least $50 \%$ bigger, and sometimes twice as large, as the smallest. Generally, approximately $70 \%$ of the variation in egg mass is due to variation between rather than within clutches, although there are some cases of extreme intra-clutch egg-size variation. Despite the large amount of variation in egg size between females, this trait is highly consistent within individuals between breeding attempts; the repeatability of egg size is generally above 0.6 and tends to be higher than that of clutch size or laying date. Heritability estimates also tend to be much higher for egg size $(>0.5)$ than for clutch size or laying date $(<0.5)$. As expected, given the high repeatability and heritability of egg size, supplemental food had no statistically significant effect on this trait in 18 out of $28(64 \%)$ studies. Where dietary supplements do increase egg size, the effect is never more than $13 \%$ of the control values and is generally much less. Similarly, ambient temperature during egg formation generally explains less than $15 \%$ of the variation in egg size. In short, egg size appears to be a characteristic of individual females, and yet the traits of a female that determine egg size are not clear. Although egg size often increases with female age (17 out of 37 studies), the change in egg size is generally less than $10 \%$. Female mass and size rarely explain more than $20 \%$ of the variation in egg size within species. A female's egg size is not consistently related to other aspects of reproductive performance such as clutch size, laying date, or the pair's ability to rear young. Physiological characteristics of the female (e.g. endogenous protein stores, oviduct mass, rate of protein uptake by ovarian follicles) show more promise as potential determinants of egg size. With regards to the consequences of egg-size variation for offspring fitness, egg size is often correlated with offspring mass and size within the first week after hatching, but the evidence for more long-lasting effects on chick growth and survival is equivocal. In other oviparous vertebrates, the magnitude of egg-size variation within populations is often as great or greater than that observed within avian populations. Although there are much fewer estimates of the repeatability of egg size in other taxa, the available evidence suggests that egg size may be more flexible within individuals. Furthermore, in non-avian species (particularly fish and turtles), it is more common for female mass or size to explain a substantial proportion of the variation in egg size. Further research into the physiological basis of egg-size variation is needed to shed light on both the proximate and ultimate causes of intraspecific variation in this trait in birds.
\end{abstract}

Key words: age, egg mass, food, intraspecific variation, optimal egg size theory, phenotypic plasticity, physiology, reproductive performance, temperature.

\section{CONTENTS}

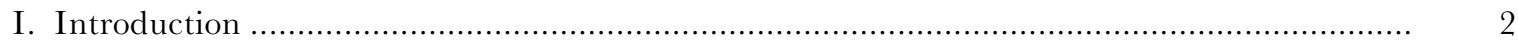

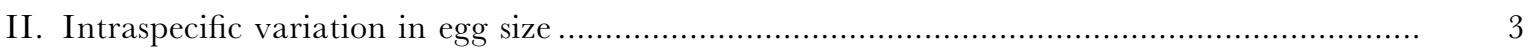

* Address for correspondence: Julian K. Christians, Institute of Cell, Animal and Population Biology, University of Edinburgh, Ashworth Laboratories, King's Buildings, West Mains Road, Edinburgh, EH9 3JT, UK. Tel.: + $44(0) 131$ 650 7334; fax: +44 (0)1316506564; e-mail: julian.christians@ed.ac.uk 


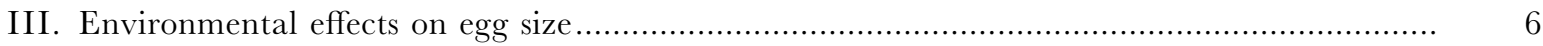

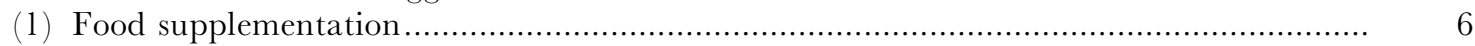

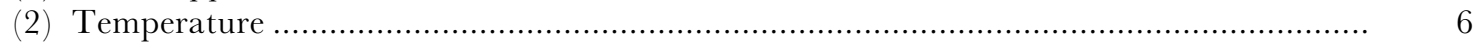

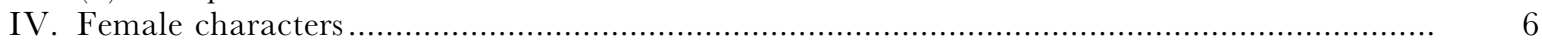

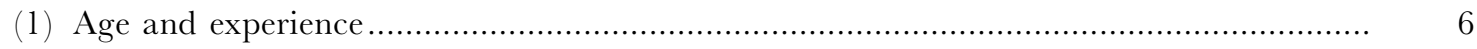

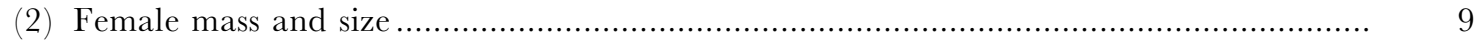

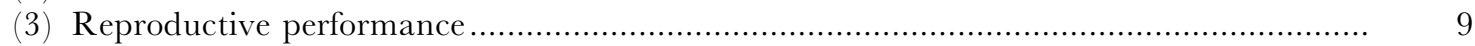

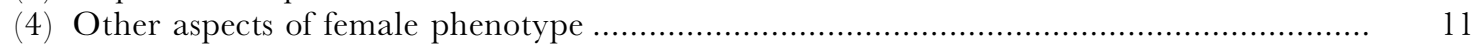

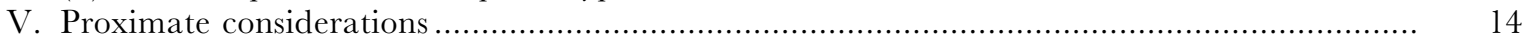

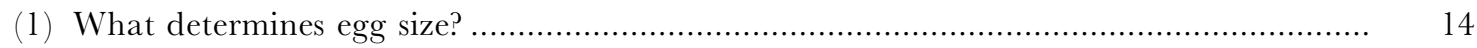

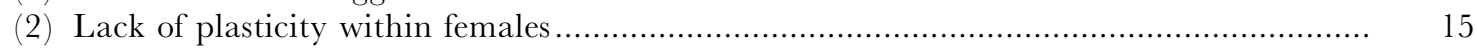

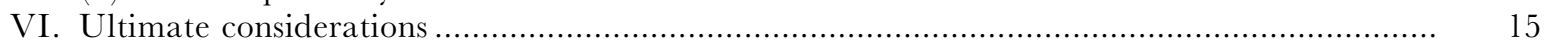

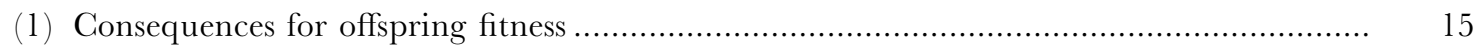

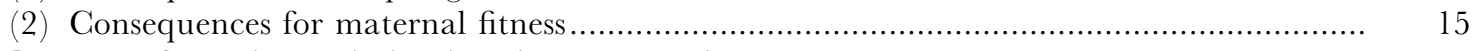

VII. Patterns of egg-size variation in other taxonomic groups ................................................ 16

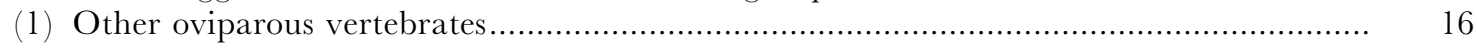

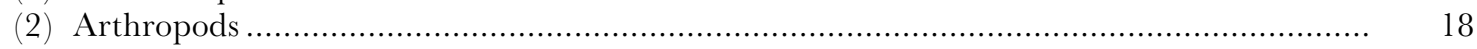

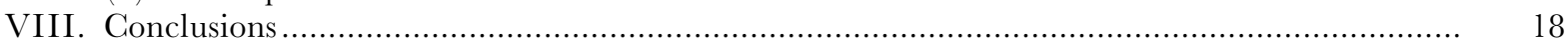

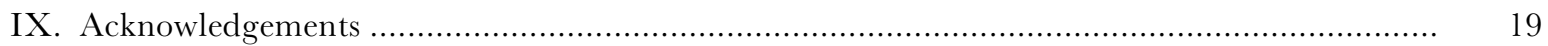

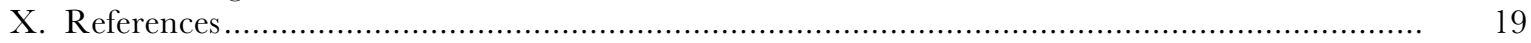

\section{INTRODUGTION}

How much should parents invest in each of their progeny? Some life-history models predict that there is an optimum amount of effort that organisms should invest in each offspring (e.g. Smith \& Fretwell, 1974; McGinley, Temme \& Geber, 1987). However, propagule size, one component of the effort expended per offspring, often shows tremendous variation within species (Bernardo, 1996). Intraspecific variation in propagule size could be due to differences in optima between individuals and environments, or to temporal changes in the optimum effort-per-offspring. Alternatively, nutritional or physical limitations might constrain the amount of resource invested in each offspring (e.g. Congdon \& Gibbons, 1987). However, to date the ubiquitous variation in propagule size within populations remains unexplained (Bernardo, 1996).

The development of better models of parental investment in offspring will require knowledge of the patterns of variation within species (e.g. whether variation occurs within or between individuals; whether variation is related to resource availability), and of the aspects of maternal phenotype that influence propagule size (Bernardo, 1996). In these respects, the ornithological literature provides a rich resource. Perhaps more than in any other taxonomic group, most aspects of egg-size variation have been extensively documented: variation within and between clutches, repeatability between clutches produced by an individual female, heritability, response to food supplementation, correlations with female phenotypes, and correlations with offspring growth and survival. In this review, I examine the patterns of intraspecific egg-size variation within avian populations and draw attention to (a) the large intraspecific variation in egg size within avian populations, (b) the lack of plasticity in egg size within individual females, and (c) our lack of understanding of the proximate or ultimate causes of intraspecific egg-size variation.

I begin by summarizing the variation in egg size within avian populations, as well as repeatability and heritability estimates of this trait. Repeatability of egg size could be due to the repeatability of environmental conditions within individuals (e.g. food supply), and so I review the effects of environmental factors (food and temperature) on egg size. Next, I summarize relationships between female characteristics (e.g. age, size) and egg size, giving special attention to physiological traits of the female that, although less intensively studied, are crucial to understanding variation in reproductive performance (Bernardo, 1996). The proximate causes and ultimate consequences of intraspecific egg-size variation are then considered. Finally, to assess the extent to which the observed patterns are unique to birds, I briefly review intraspecific egg-size variation in other taxonomic groups.

I have not included studies of domesticated species in this review because the causes of intraspecific variation present in natural populations may have been obscured or eliminated by the long history of 
artificial selection on reproductive traits. However, studies of captive, non-domesticated birds have been included since such populations commonly exhibit patterns of egg-size variation similar to those observed in nature (e.g. Williams, 1996a). Due to the enormous number of studies that have reported data on avian egg size, I have focused on variation in egg size between individuals, and generally do not consider the pattern of variation within clutches since this variation is small compared to the variation between clutches (see below) and has been reviewed elsewhere (Slagsvold et al., 1984). Throughout, I use the term egg size to refer to egg mass or volume, which are highly correlated (generally $r^{2}>0.8$; e.g. Duncan, 1987; Reid \& Boersma, 1990; Arnold, 1992; Magrath, 1992a; Meathrel et al., $1993 a$; Smith, Ottosson \& Ohlsson, 1993; Nol, Blanken \& Flynn, 1997; Viñuela, 1997; but see Flint \& Grand, 1999); where authors have provided data on both mass and volume, I use the former. Although I do not explicitly consider variation in egg quality, fresh egg mass is generally correlated with the dry

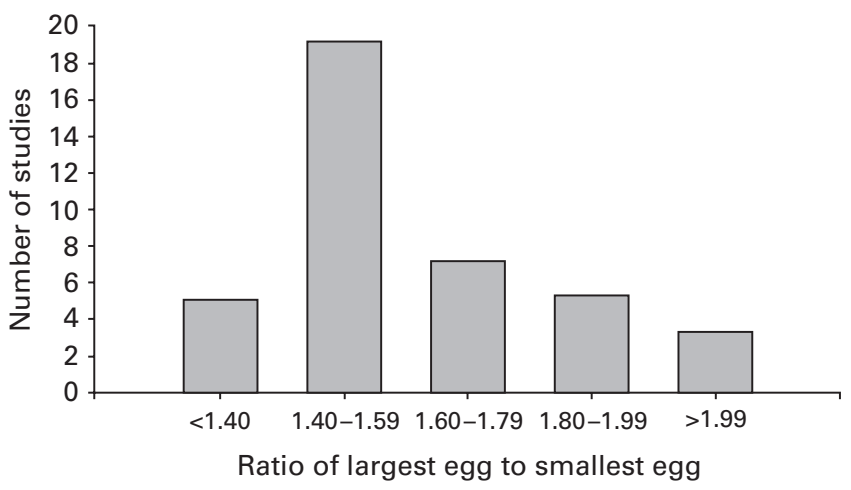

Fig. 1. The ratio of the size of the largest egg in the population to that of the smallest in 39 studies; mean egg size of the clutch was used where provided. Data are from Montevecchi et al. (1983); Bancroft (1984); Birkhead (1984); Nol et al. (1984); Murphy (1986a); Duncan (1987); Muma \& Ankney (1987); Arcese \& Smith (1988); Eldridge \& Krapu (1988); Järvinen \& Pryl (1989); Leblanc (1989); Amundsen \& Stokland (1990); Coleman \& Whittall (1990); Wiggins (1990); Hendricks (1991); Martin \& Arnold (1991); Pehrsson (1991); Croxall et al. (1992); Flint \& Sedinger (1992); Swennen \& Meer (1992); Meathrel et al. (1993a); Nilsson \& Svensson (1993a); Potti (1993); Robertson \& Cooke (1993); Smith et al. (1993); Arnold (1994); Simmons (1994); Amundsen (1995); Wiebe \& Bortolotti (1995); Amundsen et al. (1996); Dufva (1996); Weidinger (1996); Williams (1996a); Williams et al. (1996); Ashkenazi \& Yom-Tov (1997); Blomqvist et al. (1997); Erikstad et al. (1998); Smith \& Bruun (1998); Reed et al. (1999). components of the yolk and albumen (e.g. St. Clair, 1996; Kennamer, Alsum \& Colwell, 1997; Flint \& Grand, 1999) and thus is a good measure of quality in terms of macronutrient composition (see Williams, 1994 and Hill, 1995 for reviews).

\section{INTRASPEGIFIC VARIATION IN EGG SIZE}

Within many species of birds, there is a large range in egg size. The largest egg in a population is generally at least $50 \%$ bigger, and sometimes twice as large, as the smallest (Fig. 1). This variation is also seen in species with one-egg clutches, where egg size is the only means by which females can adjust the amount of nutrients and energy invested in eggs (e.g. Montevecchi et al., 1983; Croxall, Rothery \& Crisp, 1992; Meathrel et al., $1993 a$; Amundsen, 1995; Amundsen, Lorentsen \& Tveraa, 1996; Weidinger, 1996). Generally, approximately $70 \%$ of the variation in egg size is due to variation between rather than within clutches (Fig. 2). Notable exceptions to this pattern are found in the crested penguins (Eudyptes spp.) that exhibit extreme egg-size dimorphism, with differences of $30-60 \%$ between eggs within a clutch (Williams, 1990; St. Clair, 1996).

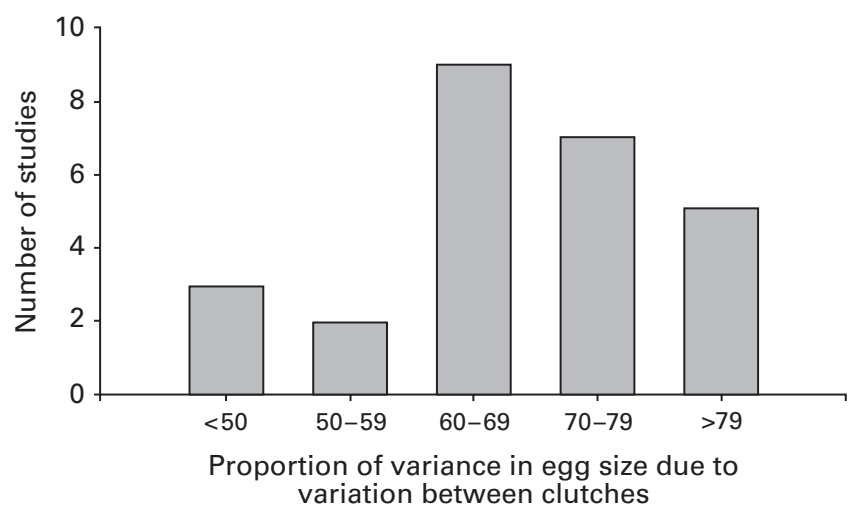

Fig. 2. Proportion of variance in egg size due to variation between rather than within clutches in 26 studies. Where more than one estimate was provided per species per study, I selected the lowest. Data are from Grant (1982); Zach (1982); Järvinen \& Väisänen (1983); Bancroft (1984); Ricklefs (1984); Lank et al. (1985); Poole (1985); Redmond (1986); Rohwer (1986); Hepp et al. (1987); Muma \& Ankney (1987); Galbraith (1988); Rohwer \& Eisenhauer (1989); Amundsen \& Stokland (1990); Coleman \& Whittall (1990); Wiggins (1990); Grant (1991); Thompson \& Hale (1991); Arnold (1992); Magrath (1992a); Swennen \& Meer (1992); Nilsson \& Svensson (1993a); Smith et al. (1993); Wiebe \& Bortolotti (1995); Nol et al. (1997); Erikstad et al. (1998). 
Table 1. Repeatabilities of egg size, clutch size and laying date between breeding attempts

\begin{tabular}{|c|c|c|c|}
\hline Latin name & Common name & Repeatability & Reference \\
\hline \multicolumn{4}{|l|}{ Egg size } \\
\hline Aegolius funereus & Tengmalm's Owl & 0.51 & Hakkarainen \& Korpimäki (1994) \\
\hline Anas acuta & Northern Pintail & 0.61 & Duncan (1987) \\
\hline Anas acuta & Northern Pintail & 0.89 & Flint \& Grand (1996) \\
\hline Anas platvrhvnchos & Mallard & 0.62 & Batt \& Prince (1979) \\
\hline Aythya marila & Greater Scaup & 0.36 & Flint \& Grand (1999) \\
\hline Branta bernicla nigricans & Black Brant & 0.78 & Flint \& Sedinger (1992) \\
\hline Branta canadensis & Canada Goose & 0.92 & Leblanc (1989) \\
\hline Charadrius semipalmatus & Semipalmated Plover & 0.68 & Nol et al. (1997) \\
\hline $\begin{array}{l}\text { Chen caerulescens } \\
\text { caerulescens }\end{array}$ & Lesser Snow Goose & 0.80 & Lessells et al. (1989) \\
\hline Falco sparverius & American Kestrel & 0.71 & Wiebe \& Bortolotti (1995) \\
\hline Ficedula hypoleuca & Pied Flycatcher & 0.61 & Potti (1993) \\
\hline Haematopus palliates & American Oystercatcher & 0.35 & Nol et al. (1984) \\
\hline Lagopus lagopus scoticus & Red Grouse & $0.73-0.77$ & Moss \& Watson (1982) \\
\hline Parus major & Great Tit & $0.58-0.72$ & Noordwijk (1987) \\
\hline Parus major & Great Tit & 0.64 & Hõrak et al. (1995) \\
\hline Parus major & Great Tit & 0.68 & Dufva $(1996)$ \\
\hline Stercorarius parasiticus & Arctic Skua & $0.63,0.73$ & Phillips \& Furness (1998) \\
\hline Sturnus vulgaris & European Starling & 0.76 & Smith et al. (1993) \\
\hline Sturnus vulgaris & European Starling & 0.76 & Christians \& Williams (2001b) \\
\hline Tachycineta bicolor & Tree Swallow & 0.77 & Wiggins (1990) \\
\hline Taeniopygia guttata & Zebra Finch & 0.74 & Williams $(1996 a)$ \\
\hline Tringa tetanus & Redshank & $0.73,0.87$ & Thompson \& Hale (1991) \\
\hline \multicolumn{4}{|l|}{ Clutch size } \\
\hline Anas platyrhynchos & Mallard & 0.54 & Batt \& Prince (1979) \\
\hline Branta bernicla nigricans & Black Brant & 0.14 & Flint \& Sedinger (1992) \\
\hline Bucephala albeola & Bufflehead & 0.55 & Gauthier (1989) \\
\hline $\begin{array}{l}\text { Chen caerulescens } \\
\text { caerulescens }\end{array}$ & Lesser Snow Goose & 0.26 & Findlay \& Cooke (1987) \\
\hline $\begin{array}{l}\text { Chen caerulescens } \\
\text { caerulescens }\end{array}$ & Lesser Snow Goose & 0.15 & Lessells et al. (1989) \\
\hline Falco tinnunculus & Kestrel & 0.19 & Meijer et al. (1988) \\
\hline Geospiza fortis & $\begin{array}{l}\text { Darwin's Medium } \\
\text { Ground Finch }\end{array}$ & 0.08 & Gibbs (1988) \\
\hline Parus major & Great Tit & 0.51 & Perrins \& Jones (1974) \\
\hline Parus major & Great Tit & $0.30-0.54$ & Noordwijk (1987) \\
\hline Parus major & Great Tit & 0.86 & Dufva $(1996)$ \\
\hline Taeniopygia guttata & Zebra Finch & 0.59 & Williams $(1996 a)$ \\
\hline \multicolumn{4}{|l|}{ Laying date } \\
\hline Accipiter nisus & Eurasian Sparrowhawk & $0.18,0.26^{\mathrm{a}}$ & Newton \& Marquiss (1984) \\
\hline Anas platvrhvnchos & Mallard & 0.57 & Batt \& Prince 1979 ) \\
\hline Bucephala albeola & Bufflehead & 0.57 & Gauthier (1989) \\
\hline Charadrius semipalmatus & Semipalmated Plover & $0.00^{\mathrm{b}}$ & Nol et al. (1997) \\
\hline $\begin{array}{l}\text { Chen caerulescens } \\
\text { caerulescens }\end{array}$ & Lesser Snow Goose & 0.22 & Hamann \& Cooke (1989) \\
\hline Falco tinnunculus & Kestrel & 0.00 & Meijer et al. (1988) \\
\hline Fulica atra & European Coot & 0.32 & Perdeck \& Cavé (1992) \\
\hline Haematopus palliates & American Oystercatcher & 0.73 & Nol et al. (1984) \\
\hline Parus major & Great Tit & $0.19-0.44$ & Noordwijk (1987) \\
\hline Stercorarius parasiticus & Arctic Skua & $-0.16,0.50$ & Phillips \& Furness (1998) \\
\hline Uria aalge & Common Murre & 0.20 & Sydeman \& Eddy (1995) \\
\hline
\end{tabular}

${ }^{a}$ Corrected values from Lessells \& Boag (1987).

${ }^{\mathrm{b}}$ Repeatability of clutch completion date, not laying date. 
Table 2. Heritability estimates for egg size, clutch size and laying date

(NS $=$ heritability estimate was not significantly different from zero and was not provided.)

\begin{tabular}{|c|c|c|c|}
\hline Latin name & Common name & Heritability & Reference \\
\hline \multicolumn{4}{|l|}{ Egg size } \\
\hline Anas acuta & Northern Pintail & NS & Duncan (1987) \\
\hline Anas platyrhynchos & Mallard & 0.55 & Prince et al. (1970) \\
\hline Branta leucopsis & Barnacle Goose & 0.67 & Larsson \& Forslund (1992) \\
\hline $\begin{array}{l}\text { Chen caerulescens } \\
\text { caerulescens }\end{array}$ & Lesser Snow Goose & 0.53 & Lessells et al. (1989) \\
\hline Ficedula hypoleuca & Pied Flycatcher & NS & Potti (1993) \\
\hline Ficedula hypoleuca & Pied Flycatcher & 0.55 & Potti (1999) \\
\hline Lagopus lagopus scoticus & Red Grouse & 0.66 & Moss \& Watson (1982) \\
\hline Parus major & Great Tit & 0.86 & Ojanen et al. (1979) \\
\hline Parus major & Great Tit & $0.66-0.86$ & Noordwijk (1987) \\
\hline Parus major & Great Tit & 0.81 & Hõrak et al. (1995) \\
\hline \multicolumn{4}{|l|}{ Clutch size } \\
\hline Anas platyrhynchos & Mallard & 0.46 & Prince et al. (1970) \\
\hline $\begin{array}{l}\text { Chen caerulescens } \\
\text { caerulescens }\end{array}$ & Lesser Snow Goose & 0.20 & Findlay \& Cooke (1987) \\
\hline $\begin{array}{l}\text { Chen caerulescens } \\
\text { caerulescens }\end{array}$ & Lesser Snow Goose & 0.17 & Lessells et al. (1989) \\
\hline Ficedula albicollis & Collared Flycatcher & 0.33 & Schluter \& Gustafsson (1993) \\
\hline Ficedula albicollis & Collared Flycatcher & 0.35 & Merila \& Sheldon (2000) \\
\hline Geospiza fortis & $\begin{array}{l}\text { Darwin's Medium } \\
\text { Ground Finches }\end{array}$ & NS & Gibbs (1988) \\
\hline Parus major & Great Tit & $0.48^{\mathrm{a}}$ & Perrins \& Jones (1974) \\
\hline Parus major & Great Tit & $0.25-0.50$ & Noordwijk (1987) \\
\hline Sturnus vulgaris & European Starling & 0.34 & Flux \& Flux (1982) \\
\hline \multicolumn{4}{|l|}{ Laying date } \\
\hline Accipiter nisus & Eurasian Sparrowhawk & NS & Newton \& Marquiss (1984) \\
\hline Ficedula albicollis & Collared Flycatcher & 0.41 & Merila \& Sheldon (2000) \\
\hline Fulica atra & Coot & 0.02 & Perdeck \& Cavé (1992) \\
\hline Parus major & Great Tit & $-0.08-0.45$ & Noordwijk (1987) \\
\hline
\end{tabular}

a Cited in Hailman (1986).

Despite such extreme dimorphism, the masses of the first- and second-laid eggs are correlated within clutches in the Macaroni Penguin (E. chrysocome; Williams, 1990), i.e. females still differ from one another in the size of egg they produce.

Egg size is highly consistent within individual females between breeding attempts. Repeatability is a measure of 'the proportion of variance in a character that occurs among rather than within individuals' (Lessells \& Boag, 1987: p. 116; see also Falconer \& Mackay, 1996) and is generally higher for egg size $(>0.6)$ than for clutch size or timing of egg laying $(<0.6$; Table 1$)$, as observed by Boag \& Noordwijk (1987) and Lessells, Cooke \& Rockwell (1989). Based on the data from Table 1, the mean repeatabilities for egg size, clutch size and timing of laying are $0.68,0.40$ and 0.35 , respectively. Even in the Macaroni Penguin, a species that shows extreme egg-size variation within clutches, the masses of the first- and second-laid eggs are positively correlated with the respective egg masses of the same female in the subsequent year $\left(r^{2}=0.27-0.67\right.$; Williams \& Croxall, 1991).

Estimates of heritability, the proportion of phenotypic variation due to additive genetic variance (Falconer \& Mackay, 1996), also tend to be higher for egg size $(>0.5)$ than for clutch size or timing of egg laying $(<0.5$; Table 2$)$ (see also Hailman, 1986; Boag \& Noordwijk, 1987; Lessells et al., 1989). Based on the data from Table 2, the mean heritabilities for egg size, clutch size and timing of laying are $0.66,0.35$ and 0.24 , respectively. It should be noted that there are a number of potential problems associated with measuring heritability in 
the wild (Hailman, 1986). For example, offspring may tend to experience similar environmental conditions as their parents, and this will inflate the apparent heritability of a trait. Thus, the heritability values provided in Table 2 may be overestimates in many cases. However, given that the heritability estimates for egg size are consistently higher than those for clutch size and laying date, it seems likely that the general pattern is robust (see also Section VI.2).

\section{ENVIRONMENTAL EFFEGTS ON EGG SIZE}

The high repeatability and heritability of egg size described above could be due to consistent or inherited environmental conditions such as food supply (e.g. due to foraging skills, social dominance, territory quality). Therefore, it is instructive to examine whether environmental factors such as food and ambient temperature can affect egg size.

\section{(1) Food supplementation}

Price (1998) and Meijer \& Drent (1999) summarized the effects of food supplementation experiments and found that supplemental food leads to an advancement of laying date more often than to an increase in egg size or clutch size. I update these reviews with a focus on egg size and the magnitude of the effect of supplemental food on this trait. Only studies that report egg-size data are included, and I consider only experimental manipulations. Studies of captive birds are included, and thus "supplemental" food may actually refer to a higher quality diet, rather than extra food. In the few studies where more than one type of diet was provided, I report the largest effect size, i.e. there is a slight bias towards large effects.

Considering only statistically significant effects, $36 \%$ of studies $(10 / 28)$ found that supplemental food or enhanced food quality increased egg size (Table 3). Clutch size was increased by supplemental food in $63 \%(15 / 24)$ of studies, and the timing of laying was advanced in $57 \%(12 / 21)$ (Table 3$)$. The increase in egg size due to food supplementation was never more than $13 \%$ of the control values and was generally much less (Högstedt, 1981: 8\%; Hill, 1988: 5\%; Hiom et al., 1991: 5-11\%; Pehrsson, 1991: 12\%; Källander \& Karlsson, 1993: 4\%; Wiebe \& Bortolotti, 1995: 7 \% ; Selman \& Houston, 1996: 13\%; Williams, 1996b: 12\%; Ramsay \& Houston, 1997: 7\%; Eldridge \& Krapu, 1988 did not provide data on the magnitude of the effect). The effect of supplemental food on reproductive parameters is likely to depend on the type of food supplied, e.g. high-protein supplements have been found to have a greater effect than lipid supplements (Williams, 1996b; Ramsay \& Houston, 1997).

In contrast to the large number of food supplementation studies, there have been relatively few food restriction experiments, and these have found no effect on egg size in Northern Bobwhite Quail (Colinus virginianus), Scaled Quail (Callipepla squamata) (Giuliano, Lutz \& Patiño, 1996) and European Starlings (Sturnus vulgaris) (Meijer \& Langer, 1995).

\section{(2) Temperature}

Only one study has experimentally examined the effect of temperature during egg production on egg size: Great Tits (Parus major) roosting in cooled nestboxes laid eggs $14 \%$ smaller than those roosting in heated nestboxes (Nager \& Noordwijk, 1992). Correlations between ambient temperatures during egg formation and egg size yield mixed results including positive (Ojanen, 1983; Järvinen \& Pryl, 1989; Järvinen, 1991; Magrath, 1992b; Nager \& Zandt, 1994) and negative (Williams \& Cooch, 1996) relationships, as well as no effect (Murphy, 1983; Robertson, 1995). Even within a species, there may be significantly positive and significantly negative relationships (Ojanen, Orell \& Väisänen, 1981). Generally, temperature explains at most $10-15 \%$ of the egg-size variation (and often much less; but see Nager \& Noordwijk, 1992). Given the lack of consistent results in the observational studies described above, more experimental studies of the effects of temperature on egg production are necessary.

\section{FEMALE GHARAGTERS}

\section{(1) Age and experience}

Saether (1990) reviewed variation in reproductive performance with age, and I update this work with a focus on egg size (i.e. only studies that report egg size data are included) and the magnitude of the changes in this trait. Although egg size appears to be a characteristic of individual females, it does increase slightly with age in many species; a statistically significant increase in egg size with age or experience was found in almost half $(17 / 37)$ of the studies 
Table 3. Effects of supplemental food or enhanced food quality on egg size, clutch size and laying date $(O=$ no significant effect (i.e. $P>0.05),+=$ positive effect (i.e. increase in egg or clutch size or advancement of laying date), $-=$ negative effect, $\mathrm{ND}=$ no data. More than one symbol indicates variation in the effect, e.g. between years or sites.)

\begin{tabular}{|c|c|c|c|c|c|}
\hline Latin name & Common name & Egg size & Clutch size & Laying date & Reference \\
\hline Aegolius funereus & Tengmalm's Owl & 0 & + & + & Korpimäki (1989) \\
\hline Anas platyrhynchos & Mallard & + & + & 0 & Eldridge \& Krapu (1988) \\
\hline Anas platyrhynchos & Mallard & + & + & ND & Pehrsson (1991) \\
\hline Circus ranivorus & $\begin{array}{l}\text { African Marsh } \\
\text { Harrier }\end{array}$ & $\bigcirc$ & + & ND & Simmons (1994) \\
\hline Corvus monedula & Jackdaw & 0 & + &,+ 0 & Soler \& Soler (1996) \\
\hline Falco sparverius & American Kestrel & + & ND & ND & Wiebe \& Bortolotti $(1995)^{\mathrm{a}}$ \\
\hline Ficedula hypoleuca & Pied Flycatcher & 0 & + & 0 & Sanz \& Moreno (1995) \\
\hline Fulica americana & American Coot & + & - & 0 & Hill (1988) \\
\hline Fulica americana & American Coot & 0 & + & + & Arnold (1994) \\
\hline Fulica atra & European Coot & 0 & ND & 0 & Horsfall $(1984)^{\mathrm{b}}$ \\
\hline Lanius collurio & Red-backed Shrike & 0 & + & ND & Carlson (1989) \\
\hline Larus fuscus & $\begin{array}{l}\text { Lesser Black-backed } \\
\text { Gull }\end{array}$ &,$+ \bigcirc$ &,$+ \bigcirc$ & 0 & Hiom et al. (1991) \\
\hline Larus fuscus & $\begin{array}{l}\text { Lesser Black-backed } \\
\text { Gull }\end{array}$ & $\bigcirc$ & $\bigcirc$ & $\bigcirc$ & Bolton et al. $(1992)^{\mathrm{C}}$ \\
\hline Melospiza melodia & Song Sparrow & 0 & + & + & Arcese \& Smith (1988) \\
\hline Pandion haliaetus & Osprey & 0 & ND & ND & Poole $(1985)$ \\
\hline Parus caeruleus & Blue Tit & 0 & ND & ND & Nilsson \& Svensson $(1993 a)$ \\
\hline Parus caeruleus & Blue Tit & 0 & 0 & + & Nilsson \& Svensson $(1993 b)$ \\
\hline Parus caeruleus & Blue Tit & 0 & 0 & + & Nilsson $(1994)^{\mathrm{a}}$ \\
\hline Parus caeruleus & Blue Tit & + & 0 & + & Ramsay \& Houston (1997) \\
\hline Parus caeruleus & Blue Tit & 0 & + & $\bigcirc^{d}$ & Ramsay \& Houston (1998) \\
\hline Parus major & Great Tit & 0 & + & + & Nager et al. (1997) \\
\hline Pica pica & Black-billed Magpie & + & $++^{e}$ & $+^{e}$ & Högstedt (1981) \\
\hline Pica pica & Black-billed Magpie & $\bigcirc$ & $\bigcirc^{d}$ &,$+ \bigcirc$ & Hochachka \& Boag (1987) \\
\hline Sturnus vulgaris & European Starling &,$+ \bigcirc$ & $\bigcirc$ & + & Källander \& Karlsson (1993) \\
\hline Taeniopygia guttata & Zebra finch & + & + & 0 & Selman \& Houston $(1996)^{\mathrm{a}}$ \\
\hline Taeniopygia guttata & Zebra finch & + &,+ 0 & ND & Williams $(1996 b)$ \\
\hline Turdus merula & Blackbird & 0 & $\bigcirc^{d}$ & + & Magrath $(1992 b)$ \\
\hline $\begin{array}{l}\text { Xanthocephalus } \\
\text { xanthocephalus }\end{array}$ & $\begin{array}{l}\text { Yellow-headed } \\
\text { Blackbird }\end{array}$ & $\bigcirc$ & $\bigcirc$ & $\bigcirc^{d}$ & Arnold (1992) \\
\hline
\end{tabular}

a Supplemental/enhanced food was provided prior to egg laying only. In all other studies, supplemental/enhanced food was provided prior to and during egg laying.

${ }^{b}$ No effect on mean egg size but there were effects on intra-clutch egg-size variation.

${ }^{c}$ No effect on mean egg size but there were effects on egg composition.

${ }^{d}$ Marginally non-significant effect $(0.05<P<0.1)$.

e Significant in paired comparisons within females only.

examined (Table 4). For comparison, statistically significant effects of age are observed more often with clutch size and timing of breeding $(69 \%, 9 / 13$ and $88 \%, 14 / 16$, respectively; Table 4 ). Of the studies I examined that reported a statistically significant increase in egg size, the difference between the most extreme age classes was generally very small (Gratto, Cooke \& Morrison, 1983: 5\%; Lequette \& Weimerskirch, 1990: 9\%; Wiggins,
1990: 2\%; Weimerskirch, 1990: 10\%; Järvinen, 1991 : 1\% ; Robertson et al., 1994: 5 \% ; Hõrak et al., 1995: 2\%; Flint \& Grand, 1996: 3\%; Viñuela, 1997: 5\%; Ollason \& Dunnet, 1986 and Flint \& Sedinger, 1992 provided no data on the magnitude of the effect), although Hipfner, Gaston \& Forest (1997) found a difference of approximately $17 \%$. Of studies that presented the data as correlations, age or experience explained only a small amount of the 
Table 4. Changes in egg size, clutch size and laying date with age (or experience, where noted) $(\sim=$ increase with age with a decline in the oldest age classes. Other symbols are as in Table 3.)

\begin{tabular}{|c|c|c|c|c|c|}
\hline Latin name & Common name & Egg size & Clutch size & $\begin{array}{l}\text { Laying } \\
\text { date }\end{array}$ & Reference \\
\hline Aegolius funereus & Tengmalm's Owl & $\bigcirc$ & ND & ND & $\begin{array}{l}\text { Hakkarainen \& Korpimäki } \\
\text { (1994) }\end{array}$ \\
\hline Aix sponsa & Wood Duck & 0 & ND & ND & Hepp et al. (1987) \\
\hline Anas acuta & Northern Pintail & 0 & ND & ND & Duncan (1987) \\
\hline Anas acuta & Northern Pintail & + & ND & ND & Flint \& Grand (1996) \\
\hline Branta bernicla nigricans & Black Brant & + & + & + & Flint \& Sedinger (1992) \\
\hline Branta canadensis & Canada Goose & $\bigcirc$ & ND & ND & Leblanc $(1989)$ \\
\hline Calidris pusilla & $\begin{array}{l}\text { Semipalmated } \\
\text { Sandpiper }\end{array}$ & + & $\bigcirc$ & $++^{\mathrm{a}}$ & Gratto et al. (1983) \\
\hline $\begin{array}{l}\text { Chen caerulescens } \\
\text { caerulescens }\end{array}$ & Lesser Snow Goose & $\bigcirc$ & + & + & Cooch et al. (1992) \\
\hline $\begin{array}{l}\text { Chen caerulescens } \\
\text { caerulescens }\end{array}$ & Lesser Snow Goose & + & ND & ND & Robertson et al. (1994) \\
\hline Corvus corone cornix & Hooded Crow & 0 & + & + & Loman $(1984)^{b}$ \\
\hline Cygnus olor & Mute Swan & 0 & + & + & Birkhead et al. (1983) \\
\hline Diomedea exulans & Wandering Albatross & + & ND & $\bigcirc^{\mathrm{a}}$ & $\begin{array}{l}\text { Lequette \& Weimerskirch } \\
(1990)^{\mathrm{b}}\end{array}$ \\
\hline Diomedea exulans & $\begin{array}{c}\text { Wandering } \\
\text { Albatross }\end{array}$ & + & $\bigcirc$ & ND & Croxall et al. (1992) \\
\hline Diomedea exulans & $\begin{array}{l}\text { Wandering } \\
\text { Albatross }\end{array}$ & $\sim$ & ND & $\bigcirc$ & Weimerskirch (1992) \\
\hline Ficedula albicollis & Collared Flycatcher & 0 & ND & ND & Cichon (1997) \\
\hline Ficedula hypoleuca & Pied Flycatcher & + & ND & ND & Järvinen (1991) \\
\hline Ficedula hypoleuca & Pied Flycatcher & - & ND & ND & Potti (1993) \\
\hline Fulica americana & American Coot & 0 & + & + & Crawford (1980) \\
\hline Fulmarus glacialis & Fulmar & + & 0 & ND & Ollason \& Dunnet $(1986)^{b}$ \\
\hline Fulmarus glacialoides & Antarctic Fulmar & + & ND & $+^{\mathrm{a}}$ & Weimerskirch $(1990)^{\mathrm{b}}$ \\
\hline Lagopus lagopus alexandrae & Willow Ptarmigan & $\bigcirc$ & ND & ND & $\begin{array}{l}\text { Sandercock \& Pedersen } \\
(1994)\end{array}$ \\
\hline Larus glaucescens & $\begin{array}{l}\text { Glaucous-winged } \\
\text { Gull }\end{array}$ & - & + & + & Reid (1988) \\
\hline Larus occidentalis & Western Gull & $\sim$ & ND & ND & Sydeman \& Emslie (1992) \\
\hline Milvus migrans & Black Kite & + & + & + & Viñuela $(1997)^{\mathrm{b}}$ \\
\hline Pandion haliaetus & Osprey & + & 0 & + & Poole (1985) \\
\hline Parus caeruleus & Blue Tit & $\bigcirc$ & ND & ND & $\begin{array}{l}\text { Nilsson \& Svensson } \\
(1993 a)\end{array}$ \\
\hline Parus major & Great Tit & 0 & ND & ND & Ojanen et al. (1979) \\
\hline Parus major & Great Tit & 0 & ND & ND & Järvinen \& Pryl (1989) \\
\hline Parus major & Great Tit & $\bigcirc$ & ND & ND & Nager \& Zandt (1994) \\
\hline Parus major & Great Tit & + & ND & ND & Hõrak et al. (1995) \\
\hline Parus major & Great Tit & $\bigcirc$ & ND & ND & Dufva $(1996)$ \\
\hline Passerculus sandwichensis & Savannah Sparrow & $\bigcirc$ & + & + & $\begin{array}{l}\text { Wheelwright \& Schultz } \\
\text { (1994) }\end{array}$ \\
\hline Sturnus vulgaris & European Starling & 0 & ND & ND & Smith et al. (1993) \\
\hline Tachycineta bicolor & Tree Swallow & + & ND & ND & Wiggins (1990) \\
\hline Tachycineta bicolor & Tree Swallow & $\bigcirc$ & + & + & Wheelwright \& Schultz \\
\hline Tringa totanus & Redshank & + & ND &,$+ \bigcirc^{\mathrm{a}}$ & Thompson \& Hale $(1991)^{b}$ \\
\hline Uria lomvia & Thick-billed Murre & + & ND & + & Hipfner et al. (1997) \\
\hline
\end{tabular}

a Some measure of timing of breeding other than laying date (i.e. date of clutch completion or date of hatching).

${ }^{\mathrm{b}}$ Effect of experience, not age. 
variation in some studies (Thompson \& Hale, 1991: 4-12\%; Croxall et al., 1992: 6\%), but explained 34-44\% in others (Poole, 1985; Hipfner et al., 1997). In some species, egg size increases from young to intermediate ages and then decreases, the greatest changes being 12-13\% (Sydeman \& Emslie, 1992; Weimerskirch, 1992), whereas in others only a decline with age is evident (Reid, 1988; Potti, 1993). Many of these studies simply compared reproductive parameters between birds of different age classes, and so apparent changes in egg size could be artifacts of selection (i.e. if survival was related to egg size). However, a few studies have also observed a change in egg size within individuals (e.g. Reid, 1988; Robertson et al., 1994).

\section{(2) Female mass and size}

Given that egg size varies little within individuals, what factors determine a female's egg size? An intuitively attractive hypothesis is that bigger females lay bigger eggs. Table 5 lists the coefficients of determination (i.e. the square of the correlation coefficients) for statistically significant relationships between egg size and female mass, size (i.e. linear measures such as tarsus, wing chord and culmen length) and "condition" (mass standardized by size using residuals as described by Bennett, 1987, or mass divided by size) in a variety of species. The coefficients of determination provide an estimate of the proportion of the variation in egg size explained by these traits (Sokal \& Rohlf, 1995). Significant positive correlations between egg size and at least one trait were observed in 33 of 50 studies and species, and a significant negative correlation was observed in only two (Redmond, 1986; Simmons, 1994). Female mass, size or condition generally explain less than $20 \%$ of the variation in egg size and the coefficient of determination was greater than 0.3 in only five studies. Furthermore, these strong relationships are not always consistent within species or even within studies (e.g. see data from Numenius americanus, Taeniopygia guttata and Vanellus vanellus in Table 5; note that Hegyi \& Sasvári (1998) found no relationship in Vanellus vanellus despite a substantial sample size, $\mathcal{N}=64$ ).

\section{(3) Reproductive performance}

Female age, mass and size provide weak indices of a female's ability to produce large eggs. Is a female's egg size related to her 'quality' as judged by other measures of reproductive performance such as clutch size, timing of laying and ability to rear young? A survey of the literature (Table 6) indicates that egg size is generally unrelated to clutch size; no relationship was found in 40 of 63 studies and species examined. Fifteen studies found a positive relationship between clutch size and egg size, whereas only five found a negative relationship. Similarly, most studies found no relationship between egg size and laying date (40 out of 69 studies and species). In those that did find a statistically significant effect, a seasonal decline in egg size was observed frequently (20 studies), but only six studies found an increase in egg size throughout the season. Decreases in egg size with laying date may be due to younger birds laying smaller eggs later (e.g. Hipfner et al., 1997; Viñuela, 1997), rather than an effect of laying date per se.

A number of studies have cross-fostered eggs (i.e. randomly switched eggs among pairs) and examined the subsequent growth and survival of the chicks. The primary goal of such studies has been to study the effects of egg size on offspring growth and survival, independent of parental quality. However, these experiments also provide an opportunity to examine the relationship between the size of egg that a female produces and the ability of the pair to raise offspring, independent of the quality of egg from which the offspring hatch. A number of such experimental studies have found no relationship between the egg mass of the foster parents and the subsequent growth and survival of the chicks they raise (Magrath, 1992c; Smith, Ohlsson \& Wettermark, 1995; Amundsen et al., 1996; Hipfner \& Gaston, 1999; Hipfner \& Gaston, 1999; Reed, Turner \& Sotherland, 1999; Styrsky, Eckerle \& Thompson, 1999; see also Meathrel et al., $1993 a$, although this study only compared large-egg females rearing small eggs and vice versa, and did not include large-egg females rearing large eggs and small-egg females rearing small eggs). Amundsen (1995) found no relationship between chick mass and foster-parent egg size, although sample sizes were relatively small $(\mathcal{N}=17$ total $)$ and females that attended chicks for a longer period of time tended to have laid larger eggs $(P=0.07$; Amundsen, 1995).

A few experimental studies have found positive correlations between the size of egg a female laid and the pair's chick-rearing abilities, including effects on chick survival (Reid \& Boersma, 1990; Bolton, 1991; Blomqvist, Johansson \& Götmark, 1997; Risch \& Rohwer, 2000) and chick size (e.g. wing length, tarsus length) but not mass (Amundsen \& Stokland, 1990; Reid \& Boersma, 1990; Risch \& Rohwer, 2000). In the Herring Gull (Larus 
Table 5. Coefficients of determination for relationships between egg size and female mass, size and condition (mass standardized by size); all relationships are positive except where noted

(Symbols are as in Table 3.)

\begin{tabular}{|c|c|c|c|c|c|}
\hline Latin name & Common name & Mass & Size & Condition & Reference \\
\hline Actitis macularia & Spotted Sandpiper & $\bigcirc$ & ND & ND & Lank et al. (1985) \\
\hline Aix sponsa & Wood Duck & 0.41 & ND & ND & Hepp et al. (1987) \\
\hline Anas acuta & Northern Pintail & 0.11 & ND & ND & Duncan (1987) \\
\hline Anas acuta & Northern Pintail & $\bigcirc^{\mathrm{a}}$ & ND & ND & Flint \& Grand (1996) \\
\hline Anas clypeata & Northern Shoveler & ND & $\bigcirc$ & ND & Rohwer (1988) \\
\hline Anas discors & Blue-winged Teal & ND & 0.06 & ND & Rohwer (1988) \\
\hline Anas platyrhynchos & Mallard & ND & $\bigcirc$ & ND & Rhymer (1988) \\
\hline Aythya marila & Greater Scaup & ND & 0 & ND & Flint \& Grand (1999) \\
\hline Branta canadensis & Canada Goose & ND & 0 & 0.18 & Leblanc (1989) \\
\hline Charadrius semipalmatus & Semipalmated Plover & 0.26 & $\bigcirc^{b}$ & 0.16 & Nol et al. (1997) \\
\hline Charadrius wilsonia & Wilson's Plover & ND & 0 & ND & Bergstrom (1988) \\
\hline $\begin{array}{l}\text { Chen caerulescens } \\
\text { caerulescens }\end{array}$ & Lesser Snow Goose & ND & $\bigcirc$ & ND & Cooch et al. (1992) \\
\hline Circus ranivorus & African Marsh Harrier & ND & $-{ }^{c}$ & ND & Simmons (1994) \\
\hline Corvus corone cornix & Hooded Crow & 0.24 & 0.26 & $\bigcirc$ & Loman (1984) \\
\hline Daption capense & Cape Petrel & ND & $0.11, \bigcirc$ & $\bigcirc$ & Weidinger (1996) \\
\hline Falco sparverius & American Kestrel & ND & 0 & $+^{d}$ & Wiebe \& Bortolotti (1995) \\
\hline Ficedula albicollis & Collared Flycatcher & $0.25-0.32$ & 0 & $0.29, \bigcirc$ & Cichon (1997) \\
\hline Ficedula hypoleuca & Pied Flycatcher & 0.07 & 0.04 & ND & Ojanen et al. (1979) \\
\hline Ficedula hypoleuca & Pied Flycatcher & $0.05, \bigcirc$ & $\bigcirc$ & ND & $\begin{array}{l}\text { Järvinen \& Väisänen } \\
\text { (1983) }\end{array}$ \\
\hline Ficedula hypoleuca & Pied Flycatcher & $0.08, \bigcirc$ & $\bigcirc$ & ND & $\begin{array}{l}\text { Järvinen \& Väisänen } \\
(1984)\end{array}$ \\
\hline Ficedula hypoleuca & Pied Flycatcher & ND & ND & $0.06-0.17$ & Slagsvold \& Lifjeld \\
\hline Ficedula hypoleuca & Pied Flycatcher & 0.1 & 0.03 & ND & Järvinen (1991) \\
\hline Ficedula hypoleuca & Pied Flycatcher & 0.08 & $0.02,0.10$ & 0.07 & Potti $(1993)$ \\
\hline Ficedula hypoleuca & Pied Flycatcher & ND & $\mathrm{ND}$ & $0.12^{\mathrm{e}}, \bigcirc^{\mathrm{b}}$ & Potti (1999) \\
\hline Haematopus palliatus & $\begin{array}{l}\text { American } \\
\text { Oystercatcher }\end{array}$ & 0.22 & 0.26 & ND & Nol et al. (1984) \\
\hline Larus fuscus & $\begin{array}{l}\text { Lesser Black-backed } \\
\text { Gull }\end{array}$ & ND & $0.18,0.20$ & ND & Bolton et al. (1993) \\
\hline Limosa limosa & Black-tailed Godwit & $\bigcirc$ & $\mathrm{ND}$ & ND & $\begin{array}{l}\text { Hegyi \& Sasväri } \\
\text { (1998) }\end{array}$ \\
\hline Numenius americanus & Long-billed Curlew & $0.07-0.59^{\mathrm{f}}$ & ND & $0.12,0.25$ & Redmond (1986) \\
\hline Numenius phaeopus & Whimbrel & $\bigcirc$ & $\bigcirc$ & $\mathrm{ND}$ & Grant (1991) \\
\hline Pandion haliaetus & Osprey & $\bigcirc$ & ND & ND & Poole $(1985)$ \\
\hline Parus caeruleus & Blue Tit & $\bigcirc^{b}$ & $\bigcirc$ & ND & $\begin{array}{l}\text { Nilsson \& Svensson } \\
(1993 a)\end{array}$ \\
\hline Parus cinctus & Siberian Tit & 0.25 & 0.18 & ND & Järvinen (1991) \\
\hline Parus major & Great Tit & 0.05 & $\bigcirc$ & ND & Ojanen et al. (1979) \\
\hline Parus major & Great Tit & 0.16 & 0 & ND & Järvinen \& Pryl (1989) \\
\hline Parus major & Great Tit & 0.12 & 0.05 & ND & Nager \& Zandt (1994) \\
\hline Parus major & Great Tit & ND & $\bigcirc$ & 0.14 & Hõrak et al. (1995) \\
\hline Parus major & Great Tit & 0.12 & 0.14 & $\bigcirc^{b}$ & Dufva (1996) \\
\hline Puffinus tenuirostris & $\begin{array}{l}\text { Short-tailed } \\
\text { Shearwater }\end{array}$ & $\mathrm{ND}$ & $\mathrm{ND}$ & $\bigcirc$ & Meathrel et al. (1993a) \\
\hline Stercorarius parasiticus & Arctic Skua & ND & $\bigcirc$ & 0.08 & $\begin{array}{l}\text { Phillips \& Furness } \\
\text { (1998) }\end{array}$ \\
\hline Sturnus vulgaris & European Starling & $\bigcirc$ & ND & ND & Meijer (1992) \\
\hline Taeniopygia guttata & Zebra Finch & 0.43 & ND & ND & $\begin{array}{l}\text { Haywood \& Perrins } \\
\text { (1992) }\end{array}$ \\
\hline
\end{tabular}


Table 5. (cont.)

\begin{tabular}{|c|c|c|c|c|c|}
\hline Latin name & Common name & Mass & Size & Condition & Reference \\
\hline Sturnus vulgaris & European Starling & ND & 0 & 0.09 & Smith et al. (1993) \\
\hline Sturnus vulgaris & European Starling & $\bigcirc$ & $\bigcirc$ & ND & $\begin{array}{l}\text { Christians \& Williams } \\
(2001 b)\end{array}$ \\
\hline Tachycineta bicolor & Tree Swallow & 0.07 & 0 & 0.05 & Wiggins $(1990)$ \\
\hline Taeniopygia guttata & Zebra Finch & ND & 0 & 0.08 & Williams (1996a) \\
\hline Tringa totanus & Redshank & 0.06 & $0.06,0.08$ & ND & $\begin{array}{l}\text { Thompson \& Hale } \\
\text { (1991) }\end{array}$ \\
\hline Tyrannus tyrannus & Eastern Kingbird & 0 & 0 & ND & Murphy $(1986 a)$ \\
\hline Vanellus vanellus & Lapwing & 0.35 & 0 & 0.31 & Galbraith (1988) \\
\hline Vanellus vanellus & Lapwing & 0.29 & 0.15 & 0.21 & $\begin{array}{l}\text { Blomqvist \& Johansson } \\
\text { (1995) }\end{array}$ \\
\hline Vanellus vanellus & Lapwing & 0 & ND & ND & Hegyi \& Sasvári (1998) \\
\hline
\end{tabular}

a Mass and size combined using principal component analysis.

${ }^{\text {b }}$ Marginally non-significant $(0.05<P<0.1)$.

c No data on strength of relationship, but significantly negative.

${ }^{d}$ Females whose eggs were above average size were in better condition.

e Condition of females at 13 days of age.

${ }^{\mathrm{f}}$ Relationship was significantly positive in two years $\left(r^{2}=0.18,0.59\right)$ and significantly negative in a third $\left(r^{2}=0.07\right)$.

argentatus), the rate of egg predation was related to the egg size of the foster parents, suggesting that egg size may be correlated with the quality of parental care during incubation (Brouwer \& Spaans, 1994).

In summary, egg size is not consistently correlated with other aspects of reproductive performance such as clutch size, timing of laying, and ability to rear chicks, although positive relationships are observed in a few species. A comprehensive discussion of trade-offs between components of reproductive effort is beyond the scope of this review, but it should be noted that a lack of negative relationships between egg size and other reproductive parameters does not necessarily indicate the absence of trade-offs [Noordwijk \& Jong, 1986; see Christians (2000) for an application of Noordwijk and Jong's (1986) model to egg size trade-offs]. Individuals may differ in the amount of resources they are able to invest in reproduction, e.g. high-quality females may be able to produce more eggs and larger eggs than lowquality females. Trade-offs can be observed when comparing females with a similar investment in eggs (e.g. total clutch mass); for instance, the finding that clutches of $\mathcal{N}$ large eggs weigh more than clutches of $\mathcal{N}+1$ small eggs (Högstedt, 1981; Bancroft, 1984; Arcese \& Smith, 1988; Rohwer \& Eisenhauer, 1989; Flint \& Sedinger, 1992; Cooke, Rockwell \& Lank, 1995; Wiebe \& Bortolotti, 1995; Flint \& Grand, 1996) indicates that some females could increase clutch size by laying smaller eggs. Alternatively, experimental manipulation can reveal trade-offs between clutch size and egg quality (Nager, Monaghan \& Houston, 2000).

\section{(4) Other aspects of female phenotype}

Three studies have attempted to manipulate female condition experimentally by clipping flight feathers and have measured the size of eggs laid subsequently. Generally, handicapping reduced clutch size but had little $(2-6 \%)$ or no effect on egg size (Slagsvold \& Lifjeld, 1988, 1990; Winkler \& Allen, 1995), even though there was some evidence that feather clipping reduced female condition as measured by breastmuscle thickness (Winkler \& Allen, 1995). Thus, handicapping did not appear to manipulate the characteristics of the female responsible for determining egg size. Dufva (1996) investigated general measures of female health and found a significant positive relationship between egg size and blood levels of haemoglobin $\left(r^{2}=0.18\right)$, but not haematocrit, in Great Tits. Furthermore, egg size was approximately $11 \%$ lower in females infected with Trypanosoma spp. than in females without this parasite (Dufva, 1996).

Houston, Jones \& Sibly (1983) related female body composition to the macronutrient composition of the oviducal egg in Lesser Black-backed Gulls 
Table 6. Correlations between egg size and other measures of primary reproductive performance (clutch size and laying date)

( $\sim$ = significant variation between clutches of different size but no linear pattern (clutch size) or a non-linear relationship (laying date). Other symbols are as in Table 3.)

\begin{tabular}{|c|c|c|c|c|}
\hline Latin name & Common name & Clutch size & Laying date & Reference \\
\hline Acrocephalus scirpaceus & Reed Warbler & ND & $\bigcirc$ & Øien et al. (1996) \\
\hline Aegolius funereus & Tengmalm's Owl & $\bigcirc$ & $\bigcirc$ & $\begin{array}{l}\text { Hakkarainen \& Korpimäki } \\
\text { (1994) }\end{array}$ \\
\hline Agelaius phoeniceus & Red-winged Blackbird & ND & $\bigcirc$ & Muma \& Ankney (1987) \\
\hline Anas acuta & Northern Pintail & 0 & $\bigcirc$ & Duncan $(1987)$ \\
\hline Anas acuta & Northern Pintail & $\bigcirc$ & $\bigcirc$ & Flint \& Grand (1996) \\
\hline Anas clypeata & Northern Shoveler & $\bigcirc$ & ND & Rohwer (1988) \\
\hline Anas discors & Blue-winged Teal & $\bigcirc$ & ND & Rohwer (1988) \\
\hline Anas platyrhynchos & Mallard & + & ND & Batt \& Prince (1979) \\
\hline Anas platyrhynchos & Mallard & $\bigcirc$ & 0 & Hill (1984) \\
\hline Anas platyrhynchos & Mallard & $\bigcirc$ & ND & Pehrsson (1991) \\
\hline Aythya fuligula & Tufted Duck & $\bigcirc$ & - & Hill (1984) \\
\hline Aythya marila & Greater Scaup & $\bigcirc$ & ND & Flint \& Grand (1999) \\
\hline Branta bernicla nigricans & Brant & + & $\bigcirc$ & Rohwer \& Eisenhauer (1989) \\
\hline Branta bernicla nigricans & Black Brant & + & - & Flint \& Sedinger (1992) \\
\hline Branta canadensis & Canada Goose & $\bigcirc$ & $\bigcirc$ & Leblanc (1989) \\
\hline Branta canadensis minima & Canada Goose & $\bigcirc$ & $\bigcirc$ & Rohwer \& Eisenhauer (1989) \\
\hline Calidris mauri & Western Sandpiper & + & - & Sandercock et al. (1999) \\
\hline Calidris pusilla & $\begin{array}{l}\text { Semipalmated } \\
\text { Sandpiper }\end{array}$ & + &,$+ \bigcirc$ & Sandercock et al. (1999) \\
\hline Charadrius morinellus & Dotterel & ND & $\bigcirc$ & Byrkjedal \& Kålås (1985) \\
\hline $\begin{array}{l}\text { Chen caerulescens } \\
\text { caerulescens }\end{array}$ & Lesser Snow Goose & $\bigcirc$ & ND & Lessells et al. (1989) \\
\hline $\begin{array}{l}\text { Chen caerulescens } \\
\text { caerulescens }\end{array}$ & Lesser Snow Goose & - & ND & Cooch et al. (1992) \\
\hline $\begin{array}{l}\text { Chen caerulescens } \\
\text { caerulescens }\end{array}$ & Lesser Snow Goose & $\bigcirc$ & ND & $\begin{array}{l}\text { Williams, Lank \& Cooke } \\
\text { (1993) }\end{array}$ \\
\hline $\begin{array}{l}\text { Chen caerulescens } \\
\text { caerulescens }\end{array}$ & Lesser Snow Goose & ND & $\bigcirc$ & Cooke et al. (1995) \\
\hline Chen canagica & Emperor Goose & $\sim$ & $\bigcirc$ & Rohwer \& Eisenhauer (1989) \\
\hline Circus ranivorus & $\begin{array}{l}\text { African Marsh } \\
\text { Harrier }\end{array}$ & $\bigcirc$ & $\bigcirc$ & Simmons (1994) \\
\hline Corvus monedula & Jackdaw & $\bigcirc$ & - & Heeb $(1994)$ \\
\hline Cygnus buccinator & Trumpeter Swan & $\bigcirc$ & ND & Rohwer \& Eisenhauer (1989) \\
\hline Cygnus olor & Mute Swan & $\bigcirc$ & $\bigcirc$ & Birkhead et al. (1983) \\
\hline Cygnus olor & Mute Swan & ND & $-{ }^{\mathrm{a}}$ & Scott \& Birkhead (1983) \\
\hline Daption capense & Cape Petrel & ND & - & Weidinger (1996) \\
\hline Egretta garzetta & Little Egret & ND & - & $\begin{array}{l}\text { Ashkenazi \& Yom-Tov } \\
(1997)\end{array}$ \\
\hline Eudyptes chrysocome & Rockhopper Penguin & ND & $\bigcirc$ & St. Clair (1996) \\
\hline Eudyptes chrysolophus & Macaroni Penguin & ND &,$- \bigcirc$ & Williams \& Croxall (1991) \\
\hline Falco sparverius & American Kestrel & $\sim$ &,$- \bigcirc$ & Wiebe \& Bortolotti (1995) \\
\hline Ficedula albicollis & Collared Flycatcher &,- 0 &,- 0 & Cichon (1997) \\
\hline Ficedula hypoleuca & Pied Flycatcher & $\bigcirc$ & 0 & Järvinen \& Väisänen (1983) \\
\hline Ficedula hypoleuca & Pied Flycatcher &,$+ \bigcirc$ & $\bigcirc$ & Järvinen \& Väisänen (1984) \\
\hline Ficedula hypoleuca & Pied Flycatcher & 0 & $\bigcirc$ & Järvinen (1991) \\
\hline Ficedula hypoleuca & Pied Flycatcher &,,$+- \bigcirc$ & $\bigcirc$ & Potti (1993) \\
\hline Ficedula hypoleuca & Pied Flycatcher & ND & $\bigcirc$ & Sanz \& Moreno (1995) \\
\hline Ficedula hypoleuca & Pied Flycatcher &,,$+- \bigcirc$ & ND & Järvinen (1996) \\
\hline Fulica americana & American Coot & + &,$- \bigcirc$ & Arnold (1994) \\
\hline Larus occidentalis & Western Gull & ND & + & Sydeman \& Emslie (1992) \\
\hline Lonchura striata & Bengalese Finch & $\sim$ & ND & Coleman \& Whittall (1990) \\
\hline
\end{tabular}


Table 6. (cont.)

\begin{tabular}{|c|c|c|c|c|}
\hline Latin name & Common name & Clutch size & Laying date & Reference \\
\hline Haematopus palliatus & American Oystercatcher & 0 &,- 0 & Nol et al. (1984) \\
\hline Lagopus lagopus scoticus & Red Grouse & 0 & ND & Moss et al. (1981) \\
\hline Larus argentatus & Herring Gull & + & ND & Hébert \& Barclay (1988) \\
\hline Milvus migrans & Black Kite & + & - & Viñuela (1997) \\
\hline Molothrus ater & $\begin{array}{l}\text { Brown-headed } \\
\text { Cowbird }\end{array}$ & ND & $\sim$ & Strausberger (1998) \\
\hline Numenius americanus & Long-billed Curlew & ND &,- 0 & Redmond (1986) \\
\hline Nycticorax nycticorax & $\begin{array}{l}\text { Black-crowned } \\
\text { Night-Heron }\end{array}$ & ND & - & Ashkenazi \& Yom-Tov (1997) \\
\hline Pagodroma nivea & Snow Petrel & ND & $\bigcirc^{\mathrm{a}}$ & Amundsen (1995) \\
\hline Pandion haliaetus & Osprey & 0 & 0 & Poole (1985) \\
\hline Parus caeruleus & Blue Tit & ND & 0 & Nilsson \& Svensson $(1993 b)$ \\
\hline Parus caeruleus & Blue Tit & 0 & 0 & Nilsson \& Svensson $(1993 a)$ \\
\hline Parus caeruleus & Blue Tit & $\bigcirc^{b}$ & 0 & Nilsson $(2000)$ \\
\hline Parus cinctus & Siberian Tit & 0 & 0 & Järvinen (1991) \\
\hline Parus major & Great Tit & 0 & 0 & Järvinen \& Pryl (1989) \\
\hline Parus major & Great Tit & 0 & 0 & Järvinen (1991) \\
\hline Parus major & Great Tit & ND & 0 & Nager \& Zandt (1994) \\
\hline Parus major & Great Tit & 0 & 0 & Dufva (1996) \\
\hline Parus major & Great Tit & ND & 0 & Nager et al. (1997) \\
\hline Phoenicurus phoenicurus & Redstart & 0 & 0 & Järvinen (1991) \\
\hline Pluvialis apricaria & Golden Plover & ND & - & Byrkjedal \& Kålås (1985) \\
\hline Puffinus tenuirostris & $\begin{array}{l}\text { Short-tailed } \\
\text { Shearwater }\end{array}$ & ND & + & Meathrel et al. $(1993 b)$ \\
\hline Pyrrhula pyrrhula & Bullfinch & + & ND & Greig-Smith et al. (1988) \\
\hline Quiscalus major & Boat-tailed Grackle & - & $\sim$ & Bancroft (1984) \\
\hline Rissa tridactyla & Kittiwake & ND & - & Runde \& Barrett (1981) \\
\hline Sayornis phoebe & Eastern Phoebe & ND &,$+ \bigcirc$ & Murphy (1994) \\
\hline Sialia sialis & Eastern Bluebird & 0 & 0 & Pinkowski (1979) \\
\hline Somateria fischeri & Spectacled Eider & 0 & ND & Rohwer \& Eisenhauer (1989) \\
\hline Somateria mollissima sedentaria & Common Eider & 0 & $\bigcirc$ & Robertson (1995) \\
\hline Somateria mollissima & Common Eider & 0 & ND & Erikstad et al. (1998) \\
\hline Sterna hirundo & Common Tern & ND & $\bigcirc$ & $\begin{array}{l}\text { Moore, Williams \& Morris } \\
(2000)\end{array}$ \\
\hline Sturnus vulgaris & European Starling & $\sim$ & ND & Greig-Smith et al. (1988) \\
\hline Sturnus vulgaris & European Starling & 0 & 0 & Meijer (1992) \\
\hline Sturnus vulgaris & European Starling &,+ 0 & 0 & Smith et al. (1993) \\
\hline Tachycineta bicolor & Tree Swallow & 0 & ND & Zach (1982) \\
\hline Tachycineta bicolor & Tree Swallow & $\sim$ & ND & Wiggins (1990) \\
\hline Taeniopygia guttata & Zebra Finch & 0 & ND & Williams $(1996 a)$ \\
\hline Troglodytes aedon & House Wren & ND & + & Styrsky et al. (1999) \\
\hline Turdus merula & Blackbird & + & ND & Greig-Smith et al. (1988) \\
\hline Turdus merula & Blackbird & 0 & + & Magrath $(1992 b)$ \\
\hline Turdus philomelos & Song Thrush & 0 & ND & Greig-Smith et al. (1988) \\
\hline Tyrannus tyrannus & Eastern Kingbird & 0 & $\bigcirc$ & Murphy (1983) \\
\hline Tyrannus tyrannus & Eastern Kingbird & ND & $\sim$ & Murphy $(1986 b)$ \\
\hline Uria lomvia & Thick-billed Murre & ND & - & Birkhead \& Nettleship (1982) \\
\hline Uria lomvia & Thick-billed Murre & ND &,- 0 & Hipfner et al. (1997) \\
\hline Vanellus vanellus & Lapwing &,$+ \bigcirc$ & $0^{\prime}$ & Galbraith (1988) \\
\hline Vanellus vanellus & Northern Lapwing & ND & - & Grønstøl (1997) \\
\hline $\begin{array}{l}\text { Xanthocephalus } \\
\text { xanthocephalus }\end{array}$ & $\begin{array}{l}\text { Yellow-headed } \\
\text { Blackbird }\end{array}$ & $\bigcirc$ & $\bigcirc$ & Arnold (1992) \\
\hline
\end{tabular}

a Date of hatching, not laying date.

b Marginally non-significant effect $(0.05<P<0.1)$. 
(Larus fuscus); protein condition (the lean dry mass of the pectoral muscles divided by the cube of the flight muscle cord) was significantly correlated with various egg components whereas body lipid content was not. The relationship between egg size and a non-destructive measure of the protein condition (derived from the profile of the flight muscles over the keel) was marginally non-significant in this species $\left(r^{2}=0.12 ; P=0.06\right.$; Bolton, Monaghan \& Houston, 1993). Protein condition (as defined by Houston et al., 1983) was also positively related to egg size in Eastern Kingbirds (Tyrannus tyrannus), and the strength of this relationship $\left(r^{2}=0.21\right.$; Murphy, 1986 b) was relatively strong compared to most correlations between egg size and female mass (Table 5). These relationships may reflect the importance of the flight muscles as endogenous stores of protein and/or specific amino acids (Houston et al., 1995a; Houston, Donnan \& Jones, 1995b). However, no relationship was found between egg size and pectoral muscle mass in the European Starling (Christians \& Williams, 2001b). Other measures of body composition such as the masses of the organs that make up the "metabolic machinery" (i.e. heart, lungs, kidneys, liver and digestive organs) also failed to explain egg-size variation in this study (Christians \& Williams, $2001 b$ ). However, oviduct mass explained approximately $21 \%$ of the variation in albumen protein content (Christians \& Williams, $2001 b$ ), suggesting that the physiological systems specific to egg production deserve further attention. For example, the rate of protein uptake into the ovarian follicles also explained a relatively large proportion $\left(r^{2}=0.24-0.50\right)$ of the variation in yolk mass in Zebra Finches (Taeniopygia guttata; Christians \& Williams, 2001 $a$ ).

A few studies have attempted to use endocrinological techniques to manipulate the reproductive performance of breeding females to investigate the physiological basis of variation in egg size and number and to elucidate trade-offs between traits. Remarkably, exogenous estradiol failed to increase egg size in both European Starlings (Christians \& Williams, 1999) and Zebra Finches (Williams, 1999), despite its roles in yolk precursor and albumen synthesis. Treatment with follicle-stimulating hormone (FSH), which is believed to stimulate ovarian follicular growth, actually reduced egg mass by approximately $10 \%$ in Zebra Finches (Christians and Williams, in press); exogenous hormone may have reduced endogenous FSH secretion via negative feedback in this experiment. The anti-estrogen tamoxifen also reduced egg size $(15 \%)$, perhaps by reducing the plasma concentration of yolk precursors below the level required to maintain normal yolk formation (Williams, 2000). No endocrinological technique has yet increased egg size in birds, although further studies with combinations of hormones may prove more successful (e.g. estradiol and FSH; Follett, Nicholls \& Redshaw, 1968).

\section{PROXIMATE GONSIDERATIONS}

\section{(1) What determines egg size?}

Bernardo (1996) pointed out that a better understanding of propagule-size variation would require a more thorough consideration of maternal phenotype. Above, I have shown that a number of female characters that are commonly measured (i.e. female age, mass and size) generally explain little of the variation in egg size in birds (although there are a few exceptions). Similarly, supplemental food increased egg size in only one-third of the studies examined, and this effect was always small $(<15 \%)$ compared to the large variation between females. Furthermore, a large amount of variation in egg size is maintained on high-quality diets (Williams, $1996 b)$. Thus, variation in the nutritional state of the female does not appear to be a general cause of eggsize variation.

Although each of the factors considered above explains at most a small proportion of the variation in egg size, it is possible that all of these factors together explain a substantial amount of the variation between females. Future work should address this possibility by analysing multiple traits simultaneously (e.g. using multiple regression) to determine the proportion of variation they explain collectively, rather than the pairwise analyses that are currently common (Bernardo, 1996). However, the factors discussed above are not completely independent (e.g. foraging skills or territory quality may improve with age, which could affect nutritional status and mass), and therefore it seems unlikely that the cumulative effect of these factors will equal the sum of their individual effects. Clearly, more work needs to be directed at the proximate causes of egg-size variation. Variation in egg size is likely to be explained, at least in part, by variation in the physiological systems involved in egg production (e.g. the production of yolk precursors by the liver and their uptake at the ovary), and yet this has received relatively little attention. Such work would enable greater physiological realism to be 
incorporated into models of egg-size evolution (Bernardo, 1996). Furthermore, with a greater understanding of proximate mechanisms, manipulation of the endocrine systems involved in egg production may offer the potential to manipulate egg size experimentally and thus investigate the costs of producing larger eggs.

\section{(2) Lack of plasticity within females}

Egg size is relatively inflexible within individual female birds, despite large variation in this trait between individuals. Some species, notably the crested penguins, regularly show dramatic variation in egg size within clutches, and so it is not clear why individuals of other species do not alter the size of eggs they produce between clutches. Flexibility in egg size would be advantageous if females could increase egg size when environmental conditions favoured offspring from larger eggs, but decrease egg mass (and so increase the number of eggs or reduce reproductive expenditure) at other times, as in other taxa (e.g. Kaplan, 1998; Fox \& Czesak, 2000; see below). The ability to adjust egg size between clutches would not be expected to be costly since the physiological mechanisms (e.g. yolk precursor production) and structures (i.e. ovary, oviduct) involved in egg formation themselves show great plasticity (Williams, 1998). Since reproductive physiology is upregulated so extensively, it is not clear why individuals could not vary the absolute extent of this upregulation in response to environmental conditions.

\section{ULTIMATE GONSIDERATIONS}

\section{(1) Consequences for offspring fitness}

Williams (1994) reviewed the consequences of intraspecific variation in egg size for offspring fitness and concluded "there is little unequivocal evidence to date of a positive relationship between egg size and offspring fitness in birds". However, relationships between chick growth and survival early in the chick-rearing period were more consistent, suggesting that the primary benefit of larger eggs might be to increase the chances of survival in the first few days after hatching (Williams, 1994). This review also pointed out that few studies had separated the effect of egg size per se from the effect of parental quality (Williams, 1994). Since then, a number of cross-fostering experiments have been performed to disentangle these factors. In general, these studies confirm earlier work: egg size is often correlated with offspring mass and size within the first week after hatching (Amundsen, 1995; Smith et al., 1995; Amundsen et al., 1996; Reed et al., 1999; Styrsky et al., 1999). In some cases, this effect is not sustained throughout the chick-rearing period (Smith et al., 1995; Amundsen et al., 1996; Reed et al., 1999; Styrsky et al., 1999; Risch \& Rohwer, 2000), whereas other traits and studies show more lasting effects (up to two weeks; Amundsen et al., 1996; Erikstad, Tveraa \& Bustnes, 1998; Hipfner \& Gaston, 1999; Styrsky et al., 1999; Hipfner, 2000; Hipfner, Gaston \& Storey, 2001). The evidence for a relationship between egg size and offspring survival during the chick-rearing period is also equivocal (no effect: Smith et al., 1995; Amundsen et al., 1996; Styrsky et al., 1999; positive effect: Blomqvist et al., 1997; Risch \& Rohwer, 2000), and there is little data regarding long-term consequences of egg size on offspring fitness (e.g. survival until breeding, Cooke et al., 1995).

Overall, the results are consistent with the idea that larger eggs may only confer an advantage in harsh, low-quality environments (Smith et al., 1995; Fox \& Czesak, 2000). In good conditions, the extended parental care provided in many avian species might compensate for small eggs and enable small hatchlings to "catch-up" with offspring from larger eggs. However, further work is necessary to test this hypothesis explicitly (e.g. Einum \& Fleming, 1999; Hipfner et al., 2001).

\section{(2) Consequences for maternal fitness}

Traits closely linked to fitness generally have low heritabilities (Gustafsson, 1986; Mousseau \& Roff, 1987). The high heritability of egg size, together with the equivocal evidence regarding the relationship between egg size and offspring fitness (see above) could be interpreted to mean that egg-size variation does not have important consequences for maternal fitness. While the existing evidence cannot rule out this possibility, this scenario would raise the question: why don't all females simply produce the smallest viable egg? Moreover, the relationship between a trait's heritability and its importance to fitness is complex (Price \& Schluter, 1991; Merila \& Sheldon, 2000), particularly since heritability incorporates a number of parameters. The narrow-sense heritability consists of the additive genetic variance divided by the phenotypic variance, the latter comprising both environmental and non-additive 
genetic variance (Falconer \& Mackay, 1996). Therefore, the high heritability of egg size could be due to relatively high additive genetic variance or relatively low environmental and non-additive genetic effects compared to other life-history traits. Furthermore, estimates of the heritability of egg size could be confounded with maternal effects to a greater extent than other traits (e.g. Potti, 1999). Even if the additive genetic variance for egg size is high, this variation could be maintained by temporally and/or spatially variable selection on egg size (Cooke et al., 1995), antagonistic pleiotropy (i.e. genetic trade-offs between egg size and other traits; Cooke et al., 1995) or frequency-dependent selection (Sinervo, Svensson \& Comendant, 2000). Further work is needed to dissect the quantitative genetics of egg size to determine why the heritability of this trait is relatively high compared to that of clutch size and laying date (i.e. the relative roles of additive genetic, non-additive genetic and environmental variance and maternal effects). In addition, a better understanding of the mechanistic basis of egg-size variation will provide clues regarding trade-offs involving egg size, and whether egg size would be expected to be under relatively tight additive genetic control (and subject to less environmental variation sensu Price \& Schluter, 1991).

\section{PATTERNS OF EGG-SIZE VARIATION IN OTHER TAXONOMIC GROUPS}

\section{(1) Other oviparous vertebrates}

Egg size varies greatly within avian populations but little within individual females. Is this phenomenon unique to birds, or is it also true in other taxonomic groups? In other oviparous vertebrates, intraspecific variation in egg size is typically as great or greater than that observed in birds (e.g. fish: Heath \& Blouw, 1998; Keckeis et al., 2000; Teather, Boswell \& Gray, 2000; amphibians: Crump, 1984; Kaplan, 1998; Cunnington \& Brooks, 2000; snakes: Ford \& Seigel, 1989; Seigel \& Ford, 1991; turtles: Bjorndal \& Carr, 1989; Iverson \& Smith, 1993; Rowe, 1995; Iverson \& Moler, 1997; Tucker \& Janzen, 1998; Tucker, Paukstis \& Janzen, 1998; lizards: Castilla \& Bauwens, 2000; Ji \& Brana, 2000; Shanbhag, Radder \& Saidapur, 2000). Unfortunately, many studies of reptiles, amphibians and fish do not describe the extent of egg-size variation within females. Intraclutch coefficients of variation are sometimes reported, but it would be useful for future studies to partition the variance into within- and between-clutch components to show explicitly whether the variation in egg size within females is large relative to that among females, and to facilitate comparison between studies. In most cases where the partitioning of variance is described, a large proportion is due to differences between clutches (i.e. females) in fish (Marsh, 1984: >50\%; Benoit \& Pepin, 1999: 83\%; Morita et al., 1999: 62\%; Berg et al., 2001: 95-97\%; but see Teather et al. 2000: 30\%) and amphibians (Beachy, 1993: 47-73\%; Cunnington \& Brooks, 2000: 70\%). In reptiles, statistically significant variation in egg size between clutches produced by different females has been reported (Sinervo, 1990; Roosenburg \& Kelley, 1996; Marco \& Perez-Mellado, 1998; Tucker \& Janzen, 1998; Steyermark \& Spotila, 2001). Thus, this pattern of variation appears similar to that in birds. However, in a more extensive review of the patterns of variation in amphibians Kaplan (1998) concluded: "the intraclutch egg size variation of an individual can itself be a small to a substantial part of the overall egg size variation observed in a population" (Kaplan, 1998; see also Crump, 1984).

Another important level of variation is that which occurs between clutches produced by the same female, but there are few studies of non-avian oviparous vertebrates that describe this variation. The repeatability of egg size ranged from 0.14 to 0.27 in the frog Bombina orientalis (Kaplan, 1998) and 0.12 to 0.35 in the Atlantic Cod Gadus morhua; Chambers \& Waiwood, 1996; Kjesbu et al., 1996). The relationship between egg size at first spawning and that at a subsequent spawning was significant $\left(r^{2}=0.13\right)$ in the Brown Trout (Salmo trutta; Jonsson \& Jonsson, 1999). Two studies of lizards measured multiple clutches per female and did not detect significant differences in egg size between females; the repeatability was not quantified (Castilla \& Bauwens, 2000; Ji \& Brana, 2000). However, significant differences in mean offspring size between females producing young in multiple breeding attempts were reported in three studies of viviparous snakes (Madsen \& Shine, 1992; Luiselli, Capula \& Shine, 1996; Bronikowski \& Arnold, 1999). Bronikowski \& Arnold (1999) estimated the repeatability of average offspring mass to be 0.43 and higher than that for litter size (0.20). Thus, although there are few studies on which to base a comparison, the consistency of egg size within individual females is not as striking in other taxa as it is in birds (see also Roosenburg \& Dunham, 1997).

There are even fewer studies of the heritability of 
Table 7. Relationships between egg size and female mass or size in oviparous vertebrates (number of studies that observed significant (SIG) or non-significant (NS) relationships). If both a significant and non-significant relationship were observed within a study (e.g. due to variation between years or populations), both types of relationship were counted (All significant relationships are positive except where noted.)

\begin{tabular}{|c|c|c|c|c|c|}
\hline \multirow[b]{2}{*}{ Taxonomic group } & \multicolumn{2}{|c|}{$\begin{array}{l}\text { Female mass } \\
\text { and egg size }\end{array}$} & \multicolumn{2}{|c|}{$\begin{array}{l}\text { Female size } \\
\text { and egg size }\end{array}$} & \multirow[b]{2}{*}{ References } \\
\hline & SIG & NS & SIG & NS & \\
\hline Oviparous fish & 3 & 3 & 4 & 7 & $\begin{array}{l}\text { Chambers \& Waiwood (1996); Kjesbu et al. (1996); } \\
\text { Lobón-Cerviá et al. (1996); Tomasini et al. (1996); } \\
\text { Morita \& Takashima (1998); Ali \& Wootton (1999a); } \\
\text { Hendry et al. (1999); Jonsson \& Jonsson (1999); Morita } \\
\text { et al. (1999); Keckeis et al. (2000); Pampoulie et al. } \\
\text { (2000); Tamate \& Maekawa (2000); Teather } \text { et al. } \\
\text { (2000) }\end{array}$ \\
\hline Amphibians & $6^{\mathrm{a}}$ & 6 & 2 & 1 & $\begin{array}{l}\text { Kuramoto (1978); Berven }(1982,1988) \text {; Williamson \& } \\
\text { Bull (1995) }\end{array}$ \\
\hline Oviparous snakes & 0 & 0 & 1 & 0 & Seigel \& Ford (1991) \\
\hline Turtles & 3 & 4 & 7 & 4 & $\begin{array}{l}\text { Bjorndal \& Carr (1989); Congdon \& Sels (1991); Iverson } \\
\text { \& Smith (1993); Rowe (1994, 1995); Iverson \& Moler } \\
\text { (1997); Roosenburg \& Dunham (1997); Tucker et al. } \\
\text { (1998); Wallis et al. (1999); Clark et al. (2001); } \\
\text { Steyermark \& Spotila (2001) }\end{array}$ \\
\hline Lizards & 6 & 2 & 6 & 10 & $\begin{array}{l}\text { Ferguson et al. (1990); Sinervo (1990); Ferguson \& } \\
\text { Talent (1993); Forsman \& Shine (1995); Michaud \& } \\
\text { Echternacht (1995); Doughty (1996, 1997); Doughty } \\
\text { \& Thompson (1998); Marco \& Perez-Mellado (1998); } \\
\text { Abell (1999); Castilla \& Bauwens (2000); Ji \& Brana } \\
\text { (2000); Ramirez-Bautista } \text { et al. (2000); Shanbhag et al. } \\
\text { (2000) }\end{array}$ \\
\hline Birds & 22 & 12 & 14 & 24 & See Table 5 \\
\hline
\end{tabular}

${ }^{a}$ One of these relationships is negative.

egg size in non-avian oviparous vertebrates; Sinervo \& Doughty (1996) provide the only estimate from a natural, free-ranging population. The heritability of egg size in the Side-blotched Lizard (Uta stansburiana) was 0.61 whereas that of laying date was 1.0 , although the latter estimate was confounded with maternal effects to a greater extent (Sinervo \& Doughty, 1996). In a preliminary study of the heritabilities of egg size and number in a captive population of this lizard, the estimate for egg size (0.24) was lower than that for clutch size (1.0; Ferguson, Snell \& Landwer, 1990). In captive rainbow trout (Oncorhynchus mykiss), one study estimated the heritabilities of egg size and number to be $0.52-0.60$ and 0.55 , respectively (Su, Liljedahl \& Gall, 1997), whereas another estimated the heritability of both of these traits to be 0.2 (Gall, 1975). While heritability estimates differ between studies and species, it is interesting that egg size does not stand out as more heritable than clutch size and laying date, as is the case in birds.

Of the potential causes of egg-size variation, female mass and size have received the most attention. Ford \& Seigel (1989) found that egg size was positively related to female size in six of 12 $(50 \%)$ species of turtles, seven of $16(44 \%)$ species of oviparous lizard and one oviparous snake. In oviparous fish, positive correlations are slightly more common, accounting for $69 \%(67 / 97)$ of the relationships summarised by Heath \& Blouw (1998); two relationships were significantly negative. I have updated these reviews (Table 7), distinguishing between female mass and linear measures of female size (e.g. snout-vent length, carapace length). In general, positive relationships between egg size and female mass or size are roughly as frequent in other oviparous vertebrates as they are in birds (Table 7). However, where relationships are significant, they 
are often much stronger than those observed in avian species; coefficients of determination commonly exceed 0.3 ( $c f$. ornithological studies, see above) and are sometimes much higher (e.g. fish: Kjesbu et al., 1996; Heath \& Blouw, 1998; Morita \& Takashima, 1998; Hendry, Berg \& Quinn, 1999; Jonsson \& Jonsson, 1999; Morita et al., 1999; Keckeis et al., 2000; Tamate \& Maekawa, 2000; amphibians: Kuramoto, 1978; turtles: Iverson \& Smith, 1993; Rowe, 1994, 1995; Wallis, Henen \& Nagy, 1999; Clark, Ewert \& Nelson, 2001; lizards: Michaud \& Echternacht, 1995; Doughty, 1996, 1997). In turtles, the size of physical apertures through which eggs must pass often limits egg size (Congdon \& Gibbons, 1987; Iverson \& Smith, 1993; Clark et al., 2001), which may explain why female size is correlated with egg size more often than is female mass (Table 7). Physical limitations may also occur in some lizard species (Michaud \& Echternacht, 1995). Female size and/or mass is also believed to play an important role in determining egg size in fish, and the variation between females is often attributed to differences to growth history (Morita et al., 1999; Berg et al., 2001; see also references in Elliott \& Hurley, 1998). Since many species of oviparous vertebrates exhibit indeterminate growth, differences in female size may be due to age. Where age has been examined, it has been found to have a large effect on egg size in a variety of taxa (fish: Keckeis et al., 2000; frog: Berven, 1988; turtle: Iverson \& Smith, 1993).

Despite the importance of female size and mass in determining egg size, high-quality diets increase clutch size without affecting egg size in fish (Wootton, 1973; Ali \& Wootton, 1999b) and snakes (Seigel \& Ford, 1991), as is often the case in birds. However, in the frog Bombina orientalis the effect of food supply on egg size was substantial compared to the amount of variation between females (Kaplan, 1987).

In summary, the magnitude of egg-size variation within populations of various oviparous vertebrates is often as great or greater than that observed within avian populations. There are few data on the repeatability of egg size between different clutches produced by the same female, but the available evidence suggests that it is lower than in birds. Furthermore, egg-size plasticity is relatively well documented in amphibians (Kaplan, 1998). A further contrast with the patterns observed in avian species is that much of the variation in egg size is often explained by female mass or size, particularly in fish and turtles. The consequences of egg size for offspring fitness also tend to be more apparent in oviparous vertebrates (fish: Heath \& Blouw, 1998; Einum \& Fleming, 1999, 2000; amphibians: Kaplan, 1998; lizards: Sinervo et al., 1992), probably because there is less parental care in these species.

\section{(2) Arthropods}

Fox \& Czesak (2000) recently reviewed patterns of progeny-size variation in arthropods and found some of the patterns to be similar to those observed in avian populations: egg size often changes with age (increasing in 11 species, decreasing in 28 and variable or not changing in 13), and there tends to be a positive relationship between egg size and female size (42 out of 79 , or $53 \%$, of the correlations examined were significantly positive), although this relationship is generally weak (Fox \& Czesak, 2000). However, in terms of variation within females their general impression was that "For many arthropods, the variation in size among progeny produced by a single female may be as large as or larger than the variation among females within a population. Much of this variation is an effect of maternal age ... but in many arthropods there is substantial variation in egg size within individual clutches of eggs" (Fox \& Czesak, 2000: p. 355).

Fox \& Czesak (2000) also discuss numerous examples of plasticity in egg size in response to food, competition, predation risk and temperature, although the magnitude of the change in egg size in response to such factors is not described.

\section{GONGLUSIONS}

1. Egg size shows a great deal of variation within avian populations but varies little within individuals. Due to the paucity of data from other taxonomic groups, it is unclear whether this pattern is unique to birds. However, the available evidence suggests that in other oviparous vertebrates and arthropods egg size may be more flexible within individuals.

2. The causes of the differences between individual female birds remain largely unknown. Few factors appear to have strong effects on egg size in avian species, even though there is probably a bias in the literature towards reporting significant relationships.

3. As a result of our lack of understanding of the proximate causes of egg-size variation, the evolutionary significance of this variation also remains unclear. For instance, while variation could be due to differences in optimum egg size between indi- 
viduals, we have no clues as to what aspects of female phenotype would determine this optimum, or why optima would vary greatly between females but not between breeding attempts within a female.

4. Further work on the physiological basis of intraspecific egg-size variation will therefore address not only mechanistic questions regarding how egg size is determined, but also ultimate questions regarding how and why intraspecific variation in life-history traits persists.

\section{AGKNOWLEDGEMENTS}

Fred Cooke helped to shape some of my ideas on the inflexibility of egg size in birds and provided a stimulating discussion of an earlier draft of this manuscript. I thank Tony D. Williams for feedback on the manuscript as well as moral and financial support. Jane I. Astbury, Pat Monaghan and two anonymous reviewers also provided helpful comments on earlier drafts of this manuscript. Allison Abell, Michelle Balk and Will Jaeckle contributed perspectives on other taxa. This research was supported by Natural Sciences and Engineering Research Council of Canada (NSERC) postgraduate and postdoctoral scholarships, a President's Research Stipend from Simon Fraser University, and by an operating grant to T. D. Williams from NSERG.

\section{REFERENGES}

Abell, A. J. (1999). Variation in clutch size and offspring size relative to environmental conditions in the lizard Sceloporus virgatus. Fournal of Herpetology 33, 173-180.

Ali, M. \& Wootton, R.J. (1999a). Coping with resource variation: effect of constant and variable intervals between feeding on reproductive performance at first spawning of female Three-spined Sticklebacks. Fournal of Fish Biology 55, 211-220.

Ali, M. \& Wootton, R.J. (1999b). Effect of variable food levels on reproductive performance of breeding female Threespined Sticklebacks. Fournal of Fish Biology 55, 1040-1053.

Amundsen, T. (1995). Egg size and early nestling growth in the Snow Petrel. Condor 97, 345-351.

Amundsen, T., Lorentsen, S.-H. \& Tveraa, T. (1996). Effects of egg size and parental quality on early nestling growth: an experiment with the Antarctic petrel. Fournal of Animal Ecology 65, 545-555.

Amundsen, T. \& Stokland, J. N. (1990). Egg size and parental quality influence nestling growth in the shag. Auk 107, 410-413.

Arcese, P. \& Smith, J. N. M. (1988). Effects of population density and supplemental food on reproduction in Song Sparrows. Fournal of Animal Ecology 57, 119-136.

Arnold, T. W. (1992). Variation in laying date, clutch size, egg size, and egg composition of Yellow-headed Blackbirds
(Xanthocephalus xanthocephalus): a supplemental feeding experiment. Canadian Fournal of Zoology 70, 1904-1911.

Arnold, T. W. (1994). Effects of supplemental food on egg production in American Coots. Auk 111, 337-350.

Ashrenazi, S. \& Yom-Tov, Y. (1997). The breeding biology of the Black-crowned Night-Heron (Nycticorax nycticorax) and the Little Egret (Egretta garzetta) at the Huleh Nature Reserve, Israel. Fournal of Zoology 242, 623-641.

Bancroft, G. T. (1984). Patterns of variation in size of Boattailed Grackle Quiscalus major eggs. Ibis 126, 496-509.

Batt, B. D. J. \& Prince, H. H. (1979). Laying dates, clutch size and egg weight of captive Mallards. Condor 81, 35-41.

BeAchy, G. K. (1993). Differences in variation in egg size for several species of salamanders (Amphibia, Caudata) that use different larval environments. Brimleyana 18, 71-82

Bennett, A. F. (1987). Interindividual variability: an underutilized resource. In New Directions in Ecological Physiology (eds. M. E. Feder, A. F. Bennett, W. W. Burggren and R. B. Huey), pp. 147-166. Cambridge University Press, Cambridge.

Benoit, H. P. \& Pepin, P. (1999). Interaction of rearing temperature and maternal influence on egg development rates and larval size at hatch in Yellowtail Flounder (Pleuronectes ferrugineus). Canadian Fournal of Fisheries and Aquatic Sciences 56, 785-794.

Berg, O. K., Hendry, A. P., Svendsen, B., Bech, C., Arnekleiv, J. V. \& Lohrmann, A. (2001). Maternal provisioning of offspring and the use of those resources during ontogeny: variation within and between Atlantic Salmon families. Functional Ecology 15, 13-23.

Bergstrom, P. W. (1988). Breeding biology of Wilson's Plovers. Wilson Bulletin 100, 25-35.

Bernardo, J. (1996). The particular maternal effect of propagule size, especially egg size: patterns, models, quality of evidence and interpretations. American Zoologist 36, 216-236.

Berven, K. A. (1982). The genetic basis of altitudinal variation in the Wood Frog Rana sylvatica.1. an experimental analysis of life-history traits. Evolution 36, 962-983.

Berven, K. A. (1988). Factors affecting variation in reproductive traits within a population of Wood Frogs (Rana sylvatica). Copeia 1988, 605-615.

BirkheAd, M. (1984). Variation in the weight and composition of Mute Swan (Cygnus olor) eggs. Condor 86, 489-490.

Birkhead, M., Bacon, P.J. \& Walter, P. (1983). Factors affecting the breeding success of the Mute Swan Cygnus olor. Journal of Animal Ecology 52, 727-741.

Birkhead, T. R. \& Nettleship, D. N. (1982). The adaptive signifcance of egg size and laying date in Thick-billed Murres Uria lomvia. Ecology 63, 300-306.

BJorndal, K. A. \& CARR, A. (1989). Variation in clutch size and egg size in the Green Turtle nesting population at Tortuguero, Costa Rica. Herpetologica 45, 181-189.

Blomovist, D. \& Johansson, O. C. (1995). Trade-offs in nest site selection in coastal populations of Lapwings Vanellus vanellus. Ibis 137, 550-558.

Blomevist, D., Johansson, O. C. \& Götmark, F. (1997). Parental quality and egg size affect chick survival in a precocial bird, the Lapwing Vanellus vanellus. Oecologia 110, $18-24$.

Boag, P. T. \& Noordwijk, A. J. v. (1987). Quantitative genetics. In Avian Genetics: A Population and Ecological Approach (eds. F. Cooke and P. A. Buckley), pp. 45-78. Academic Press, London. 
Bolton, M. (1991). Determinants of chick survival in the Lesser Black-backed Gull: relative contributions of egg size and parental quality. Fournal of Animal Ecology 60, 949-960.

Bolton, M., Houston, D. \& Monaghan, P. (1992). Nutritional constraints on egg formation in the Lesser Blackbacked gull: an experimental study. Fournal of Animal Ecology 61, 521-532.

Bolton, M., Monaghan, P. \& Houston, D. C. (1993). Proximate determination of clutch size in Lesser Black-backed Gulls: the role of food supply and body condition. Canadian Fournal of Zoology 71, 273-279.

Bronikowski, A. M. \& Arnold, S. J. (1999). The evolutionary ecology of life history variation in the Garter Snake Thamnophis elegans. Ecology 80, 2314-2325.

Brouwer, A. \& Spaans, A. L. (1994). Egg predation in the Herring Gull Larus argentatus: why does it vary so much between nests? Ardea 82, 223-231.

Byrkjedal, I. \& KÅLÅs, J. A. (1985). Seasonal variation in egg size in Golden Plover Pluvialis apricaria and Dotterel Charadrius morinellus populations. Ornis Scandinavica 16, 108-112.

Carlson, A. (1989). Courtship feeding and clutch size in Redbacked Shrikes (Lanius collurio). American Naturalist 133, 454-457.

Castilla, A. M. \& Bauwens, D. (2000). Reproductive characteristics of the island lacertid lizard Podarcis lilfordi. Fournal of Herpetology 34, 390-396.

Chambers, R. C. \& Waiwood, K. G. (1996). Maternal and seasonal differences in egg sizes and spawning characteristics of captive Atlantic Cod, Gadus morhua. Canadian Fournal of Fisheries and Aquatic Sciences 53, 1986-2003.

Christians, J. K. (2000). Trade-offs between egg size and number in waterfowl: an interspecific test of the van Noordwijk and de Jong model. Functional Ecology 14, 497-501.

Christians, J. K. \& Williams, T. D. (1999). Effects of exogenous $17 \beta$-estradiol on the reproductive physiology and reproductive performance of European Starlings (Sturnus vulgaris). Fournal of Experimental Biology 202, 2679-2685.

Christians, J. K. \& Williams, T. D. (2001 a). Interindividual variation in yolk mass and the rate of growth of ovarian follicles in the Zebra Finch (Taeniopygia guttata). Fournal of Comparative Physiology B 171, 255-261.

Christians, J. K. \& Williams, T. D. (2001 b). Intraspecific variation in reproductive physiology and egg quality in the European Starling (Sturnus vulgaris). Fournal of Avian Biology 32, 31-37.

Christians, J. K. \& Williams, T. D. (in press). Effects of porcine follicle-stimulating hormone on the reproductive performance of female Zebra Finches (Taeniopygia guttata). General and Comparative Endocrinology.

Cichon, M. (1997). Egg weight variation in Collared Flycatchers Ficedula albicollis. Ornis Fennica 74, 141-147.

Glark, P. J., Ewert, M. A. \& Nelson, C. E. (2001). Physical apertures as constraints on egg size and shape in the Common Musk Turtle, Sternotherus odoratus. Functional Ecology 15, 70-77.

Coleman, R. M. \& Whittall, R. D. (1990). Variation in egg weight in the Bengalese Finch (Lonchura striata var. domestica). Canadian Fournal of Zoology 68, 272-275.

Congdon, J. D. \& Gibbons, J. W. (1987). Morphological constraint on egg size - a challenge to optimal egg size theory? Proceedings of the National Academy of Sciences of the United States of America 84, 4145-4147.

Congdon, J. D. \& Sels, R. C. V. (1991). Growth and body size in Blandings Turtles (Emydoidea blandingi) - Relationships to reproduction. Canadian Fournal of Zoology 69, 239-245.

Cooch, E. G., Lank, D. B., Rockwell, R. F. \& Cooke, F. (1992). Is there a positive relationship between body size and fecundity in Lesser Snow Geese? Auk 109, 667-673.

Cooke, F., Rockwell, R. F. \& Lank, D. B. (1995). The Snow Geese of La Pérouse Bay: Natural Selection in the Wild. Oxford University Press, Oxford.

Crawford, R. D. (1980). Effects of age on reproduction in American Coots. Journal of Wildlife Management 44, 183-189.

Croxall, J. P., Rothery, P. \& Crisp, A. (1992). The effect of maternal age and experience on egg-size and hatching success in Wandering Albatrosses Diomedea exulans. Ibis 134, 219-228.

Crump, M. L. (1984). Intraclutch egg size variability in Hyla crucifer (Anura, Hylidae). Copeia 1984, 302-308.

Cunnington, D. G. \& Brooks, R. J. (2000). Optimal egg size theory: Does predation by fish affect egg size in Ambystoma maculatum? Fournal of Herpetology 34, 46-53.

Doughty, P. (1996). Allometry of reproduction in two species of gekkonid lizards (Gehyra) : Effects of body size miniaturization on clutch and egg sizes. Fournal of Zoology 240, 703-715.

Doughty, P. (1997). The effects of "fixed" clutch sizes on lizard life-histories: Reproduction in the Australian Velvet Gecko, Oedura lesueurii. Fournal of Herpetology 31, 266-272.

Doughty, P. \& Thompson, M. B. (1998). Unusual reproductive patterns in the Australian Marbled Gecko (Phyllodactylus marmoratus). Copeia 1998, 747-752.

Dufva, R. (1996). Blood parasites, health, reproductive success, and egg volume in female Great Tits Parus major. Fournal of Avian Biology 27, 83-87.

Duncan, D. C. (1987). Variation and heritability in egg size of the Northern Pintail. Canadian Fournal of Zoology 65, 992-996.

Einum, S. \& Fleming, I. A. (1999). Maternal effects of egg size in Brown Trout (Salmo trutta): norms of reaction to environmental quality. Proceedings of the Royal Society of London Series B-Biological Sciences 266, 2095-2100.

Einum, S. \& Fleming, I. A. (2000). Highly fecund mothers sacrifice offspring survival to maximize fitness. Nature 405, $565-567$.

Eldridge, J. L. \& Krapu, G. L. (1988). The influence of diet quality on clutch size and laying pattern in Mallards. Auk 105, $102-110$.

Elliott, J. M. \& Hurley, M. A. (1998). Predicting fluctuations in the size of newly emerged Sea-Trout fry in a Lake District stream. Fournal of Fish Biology 53, 1120-1133.

Erikstad, K. E., TveraA, T. \& Bustnes, J. O. (1998). Significance of intraclutch egg-size variation in Common Eider: the role of egg size and quality of ducklings. Fournal of Avian Biology 29, 3-9.

Falconer, D. S. \& Mackay, T. F. G. (1996). Introduction to Quantitative Genetics, Fourth Edition. Prentice Hall, Harlow, Essex.

Ferguson, G. W., Snell, H. L. \& Landwer, A. J. (1990). Proximate control of variation of clutch, egg, and body size in a West-Texas population of Uta stansburiana stejnegeri (Sauria, Iguanidae). Herpetologica 46, 227-238.

Ferguson, G. W. \& Talent, L. G. (1993). Life-history traits of the lizard Sceloporus undulatus from two populations raised in a common laboratory environment. Oecologia 93, 88-94.

Findlay, G. S. \& Cooke, F. (1987). Repeatability and heritability of clutch size in Lesser Snow Geese. Evolution 41, 453.

Flint, P. L. \& Grand, J. B. (1996). Variation in egg size of the Northern Pintail. Condor 98, 162-165. 
Flint, P. L. \& Grand, J. B. (1999). Patterns of variation in size and composition of Greater Scaup eggs: are they related? Wilson Bulletin 111, 465-471.

Flint, P. L. \& Sedinger, J. S. (1992). Reproductive implications of egg-size variation in the Black Brant. Auk 109, 896-903.

Flux, J. E. C. \& Flux, M. M. (1982). Artificial selection and gene flow in wild Starlings, Sturnus vulgaris. Naturwissenschaften 69, 96-97

Follett, B. K., Nicholls, T.J. \& Redshaw, M. R. (1968). The vitellogenic response in the South African Clawed Toad (Xenopus laevis Daudin). Gournal of Cellular Physiology 72 Supplement, 91-102.

Ford, N. B. \& Seigel, R. A. (1989). Relationships among body size, clutch size, and egg size in three species of oviparous snakes. Herpetologica 45, 75-83.

Forsman, A. \& Shine, R. (1995). Parallel geographic variation in body shape and reproductive life history within the Australian scincid lizard Lampropholis delicata. Functional Ecology 9, 818-828.

Fox, C. W. \& Czesak, M. E. (2000). Evolutionary ecology of progeny size in arthropods. Annual Review of Entomology 45, 341-369.

Galbraith, H. (1988). Effects of egg size and composition on the size, quality and survival of Lapwing Vanellus vanellus chicks. Fournal of Zoology 214, 383-398.

Gall, G. A. E. (1975). Genetics of reproduction in domesticated Rainbow Trout. Journal of Animal Science 40, 19-28.

Gauthier, G. (1989). The effect of experience and timing on reproductive performance in buffleheads. Auk 106, 568-576.

Gibbs, H. L. (1988). Heritability and selection on clutch size in Darwin's Medium Ground Finches (Geospiza fortis). Evolution 42, 750-762.

Giuliano, W. M., Lutz, R. S. \& Patiño, R. (1996). Reproductive responses of adult female Northern Bobwhite and Scaled Quail to nutritional stress. Fournal of Wildlife Management 60, 302-309.

Grant, M. C. (1991). Relationships between egg size, chick size at hatching, and chick survival in the Whimbrel Numenius phaeopus. Ibis 133, 127-133.

Grant, P. R. (1982). Variation in the size and shape of Darwin's Finch eggs. Auk 99, 15-23.

Gratto, G. L., Cooke, F. \& Morrison, R. I. G. (1983). Nesting success of yearling and older breeders in the Semipalmated Sandpiper, Calidris pusilla. Canadian fournal of Zoology 61, 1133-1137.

Greig-Smith, P. W., Feare, C. J., Freeman, E. M. \& Spencer, P. L. (1988). Causes and consequences of egg-size variation in the European Starling Sturnus vulgaris. Ibis 130, 1-10.

Grønstøl, G. B. (1997). Correlates of egg-size variation in polygynously breeding Northern Lapwings. Auk 114, 507-512.

Gustafsson, L. (1986). Lifetime reproductive success and heritability: empirical support for Fisher's fundamental theorem. American Naturalist 128, 761-764.

Hailman, J. P. (1986). The heritability concept applied to wild birds. In Current Ornithology, Volume 4 (ed. R. F. Johnston), pp. 71-95. Plenum Press, New York.

Hakkarainen, H. \& Korpimäki, E. (1994). Environmental, parental and adaptive variation in egg size of Tengmalm's Owls under fluctuating food conditions. Oecologia 98, 362-368.

Hamann, J. \& Cooke, F. (1989). Intra-seasonal decline of clutch size in Lesser Snow Geese. Oecologia 79, 83-90.
Haywood, S. \& Perrins, C. M. (1992). Is clutch size in birds affected by environmental conditions during growth? Proceedings of the Royal Society of London Series B 249, 195-197.

Heath, D. D. \& Blouw, D. M. (1998). Are maternal effects in fish adaptive or merely physiological side effects? In Maternal effects as adaptations (eds. T. A. Mousseau and C. W. Fox), pp. 178-201. Oxford University Press, Oxford.

Hébert, P. N. \& Barclay, R. M. R. (1988). Parental investment in Herring Gulls: clutch apportionment and chick survival. Condor 90, 332-338.

Heeb, P. (1994). Intraclutch egg-mass variation and hatching asynchrony in the Jackdaw Corvus monedula. Ardea 82, 287-297.

Hegyi, Z. \& Sasvári, L. (1998). Components of fitness in Lapwings Vanellus vanellus and Black-tailed Godwits Limosa limosa during the breeding season: do female body mass and egg size matter? Ardea 86, 43-50.

Hendricks, P. (1991). Repeatability of size and shape of American Pipit eggs. Canadian Fournal of Zoology 69, 2624-2628.

Hendry, A. P., Berg, O. K. \& Quinn, T. P. (1999). Condition dependence and adaptation-by-time: breeding date, life history, and energy allocation within a population of salmon. Oikos 85, 499-514.

Hepp, G. R., Stangohr, D. J., Baker, L. A. \& Kennamer, R. A. (1987). Factors affecting variation in the egg and duckling components of Wood Ducks. Auk 104, 435-443.

Hill, D. A. (1984). Laying date, clutch size and egg size of the Mallard Anas platyrhynchos and Tufted Duck Aythya fuligula. Ibis 126, 484-495.

Hill, W. L. (1988). The effect of food abundance on the reproductive patterns of Coots. Condor 90, 324-331.

Hill, W. L. (1995). Intraspecific variation in egg composition. Wilson Bulletin 107, 382-387.

Hiom, L., Bolton, M., Monaghan, P. \& Worrall, D. (1991). Experimental evidence for food limitation of egg production in gulls. Ornis Scandinavica 22, 94-97.

Hipfner, J. M. (2000). The effect of egg size on post-hatching development in the Razorbill: an experimental study. Fournal of Avian Biology 31, 112-118.

Hipfner, J. M. \& Gaston, A. J. (1999). The relationship between egg size and posthatching development in the Thickbilled Murre. Ecology 80, 1289-1297.

Hipfner, J. M., Gaston, A. J. \& Forest, L. N. D. (1997). The role of female age in determining egg size and laying date of Thick-billed Murres. Gournal of Avian Biology 28, 271-278.

Hipfner, J. M., Gaston, A. J. \& Storey, A. E. (2001). Food supply and the consequences of egg size in the Thick-billed Murre. Condor 103, 240-247.

Hochachka, W. M. \& Boag, D. A. (1987). Food shortage for breeding Black-billed Magpies (Pica pica): an experiment using supplemental food. Canadian Fournal of Zoology 65, 1270-1274.

Högstedt, G. (1981). Effect of additional food on reproductive success in the Magpie (Pica pica). Fournal of Animal Ecology 50, 219-229.

Hõrak, P., Mänd, R., Ots, I. \& Leivits, A. (1995). Egg size in the Great Tit Parus major: individual, habitat and geographic differences. Ornis Fennica 72, 97-114.

Horsfall, J. A. (1984). Food supply and egg mass variation in the European Coot. Ecology 65, 89-95.

Houston, D. C., Donnan, D., Jones, P., Hamilton, I. \& Osborne, D. $(1995 a)$. Changes in the muscle condition of 
female Zebra Finches Poephila guttata during egg laying and the role of protein storage in bird skeletal muscle. Ibis 137, $322-328$.

Houston, D. C., Donnan, D. \& Jones, P. J. (1995b). The source of the nutrients required for egg production in Zebra Finches Poephila guttata. Fournal of Zoology 235, 469-483.

Houston, D. C., Jones, P. J. \& Sibly, R. M. (1983). The effect of female body condition on egg laying in Lesser Black-backed Gulls Larus fuscus. Fournal of Zoology 200, 509-520.

Iverson, J. B. \& Moler, P. E. (1997). The female reproductive cycle of the Florida Softshell Turtle (Apalone ferox). Fournal of Herpetology 31, 399-409.

Iverson, J. B. \& Smith, G. R. (1993). Reproductive ecology of the Painted Turtle (Chrysemys picta) in the Nebraska sandhills and across its range. Copeia $1993,1-21$.

Järvinen, A. (1991). Proximate factors affecting egg volume in subarctic hole-nesting passerines. Ornis Fennica 68, 99-104.

Järvinen, A. (1996). Correlation between egg size and clutch size in the Pied Flycatcher Ficedula hypoleuca in warm and cold summers. Ibis 138, 620-623.

Järvinen, A. \& Pryl, M. (1989). Egg dimensions of the Great Tit Parus major in southern Finland. Ornis Fennica 66, 69-74.

Järvinen, A. \& Värsänen, R. A. (1983). Egg size and related reproductive traits of a southern passerine Ficedula hypoleuca breeding in an extreme northern environment. Ornis Scandinavica 14, 253-262.

Järvinen, A. \& Väisänen, R. A. (1984). Reproduction of Pied Flycatchers (Ficedula hypoleuca) in good and bad breeding seasons in a northern marginal area. Auk 101, 439-450.

Ji, X. A. \& BRana, F. (2000). Among clutch variation in reproductive output and egg size in the Wall Lizard (Podarcis muralis) from a lowland population of northern Spain. Fournal of Herpetology 34, 54-60.

Jonsson, N. \& Jonsson, B. (1999). Trade-off between egg mass and egg number in Brown Trout. Fournal of Fish Biology 55, 767-783.

Källander, H. \& Karlsson, J. (1993). Supplemental food and laying date in the European Starling. Condor 95, 1031-1034.

Kaplan, R. H. (1987). Developmental plasticity and maternal effects of reproductive characteristics in the frog, Bombina orientalis. Oecologia 71, 273-279.

KaPlan, R. H. (1998). Maternal effects, developmental plasticity, and life history evolution: an amphibian model. In Maternal effects as adaptations (eds. T. A. Mousseau and C. W. Fox), pp. 244-260. Oxford University Press, Oxford.

Kegkeis, H., Bauer-Nemeschinal, E., Menshutkin, V. V., Nemeschkal, H. L. \& Kamler, E. (2000). Effects of female attributes and egg properties on offspring viability in a rheophilic cyprinid, Chondrostoma nasus. Canadian Gournal of Fisheries and Aquatic Sciences 57, 789-796.

Kennamer, R. A., Alsum, S. K. \& Colwell, S. V. (1997). Composition of Wood Duck eggs in relation to egg size, laying sequence and skipped days of laying. Auk 114, 479-487.

KJesbu, O. S., Solemdal, P., Bratland, P. \& Fonn, M. (1996). Variation in annual egg production in individual captive Atlantic Cod (Gadus morhua). Canadian Fournal of Fisheries and Aquatic Sciences 53, 610-620.

KorpimäKI, E. (1989). Breeding performance of Tengmalm's Owl Aegolius funereus: effects of supplementary feeding in a peak vole year. Ibis 131, 51-56.

Kuramoto, M. (1978). Correlations of quantitative parameters of fecundity in amphibians. Evolution 32, 287-296.
Lank, D. B., Oring, L. W. \& Maxson, S. J. (1985). Mate and nutrient limitation of egg-laying in a polyandrous shorebird. Ecology 66, 1513-1524.

Larsson, K. \& Forslund, P. (1992). Genetic and social inheritance of body and egg size in the Barnacle Goose (Branta leucopsis). Evolution 46, 235-244.

Leblanc, Y. (1989). Variation in size and eggs of captive and wild Canada Geese. Ornis Scandinavica 20, 93-98.

Lequette, B. \& Weimerskirch, H. (1990). Influence of parental experience on the growth of Wandering Albatross chicks. Condor 92, 726-731.

Lessells, C. M. \& Boag, P. T. (1987). Unrepeatable repeatabilities: a common mistake. Auk 104, 116-121.

Lessells, C. M., Cooke, F. \& Rogkwell, R. F. (1989). Is there a trade-off between egg weight and clutch size in wild Lesser Snow Geese (Anser c. caerulescens). Fournal of Evolutionary Biology 2, 457-472.

Lobón-Cerviá, J., Dgebuadze, Y., Utrilla, G. G., Rincón, P. A. \& Granado-Lorencio, C. (1996). The reproductive tactics of dace in central Siberia: Evidence for temperature regulation of the spatio-temporal variability of its life history. Journal of Fish Biology 48, 1074-1087.

Loman, J. (1984). Breeding success in relation to parent size and experience in a population of the Hooded Crow. Ornis Scandinavica 15, 183-187.

Luiselli, L., Capula, M. \& Shine, R. (1996). Reproductive output, costs of reproduction, and ecology of the Smooth Snake, Coronella austriaca, in the eastern Italian Alps. Oecologia 106, 100-110.

Madsen, T. \& Shine, R. (1992). Determinants of reproductive success in female Adders, Vipera Berus. Oecologia 92, 40-47.

Magrath, R. D. (1992a). Roles of egg mass and incubation pattern in establishment of hatching hierarchies in the Blackbird (Turdus merula). Auk 109, 474-487.

Magrath, R. D. (1992b). Seasonal changes in egg-mass within and among clutches of birds: general explanations and a field study of the Blackbird Turdus merula. Ibis 134, 171-179.

Magrath, R. D. (1992c). The effect of egg mass on the growth and survival of Blackbirds: a field experiment. Fournal of Zoology 227, 639-653.

Marco, A. \& Perez-Mellado, V. (1998). Influence of clutch date on egg and hatchling sizes in the annual clutch of Lacerta schreiberi (Sauria, Lacertidae). Copeia 1998, 145-150.

Marsh, E. (1984). Egg size variation in central Texas populations of Etheostoma spectabile (Pisces, Percidae). Copeia 1984, 291-301.

Martin, P. A. \& Arnold, T. W. (1991). Relationships among fresh mass, incubation time, and water loss in Japanese Quail eggs. Condor 93, 28-37.

Maginley, M. A., Temme, D. H. \& Geber, M. A. (1987). Parental investment in offspring in variable environments: theoretical and empirical considerations. American Naturalist 130, 370-398.

Meathrel, C. E., Bradley, J. S., Wooller, R. D. \& Skira, I. J. (1993a). The effect of parental condition on egg-size and reproductive success in Short-tailed Shearwaters Puffinus tenuirostris. Oecologia 93, 162-164.

Meathrel, C. E., Skira, I. J., Bradley, J. S. \& Wooller, R. D. $(1993 b)$. The influence of egg-size, mass and composition upon hatching success in the Short-tailed Shearwater Puffinus tenuirostris (Aves: Procellariiformes). Fournal of Zoology 230, 679-686. 
Meijer, T. (1992). Egg-laying patterns in captive Starlings. Ardea 80, 301-310.

Mejjer, T., Daan, S. \& Dijkstra, C. (1988). Female condition and reproduction: effects of food manipulation in free-living and captive Kestrels. Ardea 76, 141-154.

Meijer, T. \& Drent, R. (1999). Re-examination of the capital and income dichotomy in breeding birds. Ibis 141, 399-414.

Mejer, T. \& Langer, U. (1995). Food availability and egglaying of captive European Starlings. Condor 97, 718-728.

Merila, J. \& Sheldon, B. C. (2000). Lifetime reproductive success and heritability in nature. American Naturalist 155, 301-310.

Michaud, E. J. \& Echternacht, A. C. (1995). Geographic variation in the life-history of the lizard Anolis carolinensis and support for the pelvic constraint model. Fournal of Herpetology 29, 86-97.

Montevegchi, W. A., Kirkham, I. R., Roby, D. D. \& Brink, K. L. (1983). Size, organic composition, and energy content of Leach's Storm-petrel (Oceanodroma leucorhoa) eggs with reference to position in the precocial-altricial spectrum and breeding ecology. Canadian Fournal of Zoology 61, 1457-1463.

Moore, D. J., Williams, T. D. \& Morris, R. D. (2000). Mateprovisioning, nutritional requirements for egg production, and primary reproductive effort of female Common Terns Sterna hirundo. Fournal of Avian Biology 31, 183-196.

Morita, K. \& Takashima, Y. (1998). Effect of female size on fecundity and egg size in White- Spotted Charr: comparison between sea-run and resident forms. Fournal of Fish Biology 53, 1140-1142.

Morita, K., Yamamoto, S., Takashima, Y., Matsuishi, T., Kanno, Y. \& Nishimura, K. (1999). Effect of maternal growth history on egg number and size in wild White-Spotted Char (Salvelinus leucomaenis). Canadian Journal of Fisheries and Aquatic Sciences 56, 1585-1589.

Moss, R. \& Watson, A. (1982). Heritability of egg size, hatch weight, body weight, and viability in Red Grouse (Lagopus lagopus scoticus). Auk 99, 683-686.

Moss, R., Watson, A., Rothery, P. \& Glennie, W. W. (1981). Clutch size, egg size, hatch weight and laying date in relation to early mortality in Red Grouse Lagopus lagopus scoticus chicks. Ibis 123, 450-462.

Mousseau, T. A. \& Roff, D. A. (1987). Natural selection and the heritability of fitness components. Heredity 59, 181-197.

Muma, K. E. \& Ankney, C. D. (1987). Variation in weight and composition of Red-winged Blackbird eggs. Canadian Fournal of Zoology 65, 605-607.

Murphy, M. T. (1983). Ecological aspects of the reproductive biology of Eastern Kingbirds: geographic comparisons. Ecology 64, 914-928.

Murphy, M. T. (1986a). Body size and condition, timing of breeding, and aspects of egg production in Eastern Kingbirds. Auk 103, 465-476.

Murphy, M. T. (1986b). Temporal components of reproductive variability in Eastern Kingbirds (Tyrannus tyrannus). Ecology 67, 1483-1492.

Murphy, M. T. (1994). Breeding patterns of Eastern Phoebes in Kansas: adaptive strategies or physiological constraint? Auk 111, 617-633.

Nager, R. G., Monaghan, P. \& Houston, D. G. (2000). Within-clutch trade-offs between the number and quality of eggs: experimental manipulations in Gulls. Ecology 81, 1339-1350.
Nager, R. G. \& Noordwijk, A. J. v. (1992). Energetic limitation in the egg-laying period of Great Tits. Proceedings of the Royal Society of London Series B 249, 259-263.

Nager, R. G., Rǘgger, C. \& Noordwijk, A. J. v. (1997). Nutrient or energy limitation on egg formation: a feeding experiment in Great Tits. Fournal of Animal Ecology 66, 495-507.

NAGer, R. G. \& Zandt, H. S. (1994). Variation in egg size in Great Tits. Ardea 82, 315-328.

Newton, I. \& Marquiss, M. (1984). Seasonal trend in the breeding performance of Sparrowhawks. Fournal of Animal Ecology 53, 809-829.

Nilsson, J.-A. (1994). Energetic bottle-necks during breeding and the reproductive cost of being too early. Fournal of Animal Ecology 63, 200-208.

Nilsson, J.-A. (2000). Time-dependent reproductive decisions in the Blue Tit. Oikos 88, 351-361.

Nilsson, J.-Å. \& Svensson, E. (1993a). Causes and consequences of egg mass variation between and within Blue Tit clutches. Fournal of Zoology 230, 469-481.

Nilsson, J.-A. \& Svensson, E. (1993b). Energy constraints and ultimate decisions during egg-laying in the Blue Tit. Ecology 74, 244-251.

Nol, E., Baker, A. J. \& Cadman, M. D. (1984). Clutch initiation dates, clutch size, and egg size of the American Oystercatcher in Virginia. Auk 101, 855-867.

Nol, E., Blanken, M. S. \& Flynn, L. (1997). Sources of variation in clutch size, egg size and clutch completion dates of Semipalmated Plovers in Churchill, Manitoba. Condor 99, 389-396.

Noordwijk, A. J. v. (1987). Quantitative ecological genetics of Great Tits. In Avian Genetics: A Population and Ecological Approach (eds. F. Cooke and P. A. Buckley), pp. 363-380. Academic Press, London.

Noordwijk, A. J. v. \& Jong, G. D. (1986). Acquisition and allocation of resources: their influence on variation in life history tactics. American Naturalist 128, 137-142.

Øien, I. J., Honza, M., Moksnes, A. \& Røskaft, E. (1996). The risk of parasitism in relation to the distance from Reed Warbler nests to Cuckoo perches. Journal of Animal Ecology 65, 147-153.

OJanen, M. (1983). Effects of laying sequence and ambient temperature on the composition of eggs of the Great Tit Parus major and the Pied Flycatcher Ficedula hypoleuca. Annales Zoologici Fennici 20, 65-71.

Ojanen, M., Orell, M. \& Väisänen, R. A. (1979). Role of heredity in egg size variation in Great Tit Parus major and the Pied Flycatcher Ficedula hypoleuca. Ornis Scandinavica 10, 22-28.

Ojanen, M., Orell, M. \& Väisänen, R. A. (1981). Egg size variation within passerine clutches: effects of ambient temperature and laying sequence. Ornis Fennica 58, 93-108.

Ollason, J. G. \& Dunnet, G. M. (1986). Relative effects of parental performance and egg quality on breeding success of Fulmars Fulmarus glacialis. Ibis 128, 290-296.

Pampoulie, C., Boughereau, J. L., Rosecchi, E., Poizat, G. \& Crivelli, A. J. (2000). Annual variations in the reproductive traits of Pomatoschistus microps in a Mediterranean lagoon undergoing environmental changes: evidence of phenotypic plasticity. Journal of Fish Biology 57, 1441-1452.

Penrsson, O. (1991). Egg and clutch size in the mallard as related to food quality. Canadian Journal of Zoology 69, 156-162.

Perdeck, A. G. \& Gavé, A. J. (1992). Laying date in the coot: 
effects of age and mate choice. Fournal of Animal Ecology 61, 13-19.

Perrins, G. M. \& Jones, P. J. (1974). The inheritance of clutch size in the Great Tit (Parus major L.). Condor 76, 225-229.

Phillips, R. A. \& Furness, R. W. (1998). Repeatability of breeding parameters in Arctic Skuas. Fournal of Avian Biology 29, 190-196.

Pinkowski, B. C. (1979). Effect of nesting history on egg size in Eastern Bluebirds. Condor 81, 210.

Poole, A. (1985). Courtship feeding and Osprey reproduction. Auk 102, 479-492.

Ротті, J. (1993). Environmental, ontogenetic, and genetic variation in egg size in Pied Flycatchers. Canadian Fournal of Zoology 71, 1534-1542.

Pотті, J. (1999). Maternal effects and the pervasive impact of nestling history on egg size in a passerine bird. Evolution 53, 279-285.

Price, T. (1998). Maternal and paternal effects in birds: effects on offspring fitness. In Maternal effects as adaptations (eds. T. A. Mousseau and C. W. Fox), pp. 202-226. Oxford University Press, Oxford.

Price, T. \& Schluter, D. (1991). On the low heritability of life-history traits. Evolution 45, 853-861.

Prince, H. H., Siegel, P. B. \& Cornwell, G. W. (1970). Inheritance of egg production and juvenile growth in Mallards. Auk 87, 342-352.

Ramirez-Bautista, A., Balderas-Valdivia, G. \& Vitt, L. J. (2000). Reproductive ecology of the Whiptail Lizard Cnemidophorus lineatissimus (Squamata: Teiidae) in a tropical dry forest. Copeia 2000, 712-722.

Ramsay, S. L. \& Houston, D. C. (1997). Nutritional constraints on egg production in the Blue Tit: a supplementary feeding study. Fournal of Animal Ecology 66, 649-657.

Ramsay, S. L. \& Houston, D. C. (1998). The effect of dietary amino acid composition on egg production in Blue Tits. Proceedings of the Royal Society of London Series B 265, 1401-1405.

Redmond, R. L. (1986). Egg size and laying date of Long-billed Curlews Numenius americanus: implications for female reproductive tactics. Oikos 46, 330-338.

Reed, W. L., Turner, A. M. \& Sotherland, P. R. (1999). Consequences of egg-size variation in the Red-winged Blackbird. Auk 116, 549-552.

ReID, W. V. (1988). Age-specific patterns of reproduction in the Glaucous-winged Gull: increased effort with age? Ecology 69, 1454-1465.

Reid, W. V. \& Boersma, P. D. (1990). Parental quality and selection on egg size in the Magellanic Penguin. Evolution 44, 1780-1786.

Rhymer, J. M. (1988). The effect of egg size variability on thermoregulation of Mallard (Anas platyrhynchos) offspring and its implications for survival. Oecologia 75, 20-24.

Ricklefs, R. E. (1984). Variation in the size and composition of eggs of the European Starling. Condor 86, 1-6.

Risch, T. S. \& Rohwer, F. C. (2000). Effects of parental quality and egg size on growth and survival of Herring Gull chicks. Canadian Journal of Zoology 78, 967-973.

Robertson, G. J. (1995). Annual variation in Common Eider egg size: effects of temperature, clutch size, laying date, and laying sequence. Canadian Fournal of Zoology 73, 1579-1587.

Robertson, G. J., Cooch, E. G., Lank, D. B., Rockwell, R. F. \& Cooke, F. (1994). Female age and egg size in the Lesser Snow Goose. Fournal of Avian Biology 25, 149-155.
Robertson, G.J. \& Cooke, F. (1993). Intraclutch egg-size variation and hatching success in the Common Eider. Canadian Journal of Zoology 71, 544-549.

Rohwer, F. C. (1986). Composition of Blue-winged Teal eggs in relation to egg size, clutch size and the timing of laying. Condor 88, 513-519.

Rohwer, F. C. (1988). Inter- and intraspecific relationships between egg size and clutch size in waterfowl. Auk 105, 161-176.

Rohwer, F. C. \& Eisenhauer, D. I. (1989). Egg mass and clutch size relationships in geese, eiders, and swans. Ornis Scandinavica 20, 43-48.

Roosenburg, W. M. \& Dunham, A. E. (1997). Allocation of reproductive output: Egg- and clutch-size variation in the Diamondback Terrapin. Copeia 1997, 290-297.

Roosenburg, W. M. \& Kelley, K. G. (1996). The effect of egg size and incubation temperature on growth in the turtle, Malaclemys terrapin. Fournal of Herpetology 30, 198-204.

Rowe, J. W. (1994). Reproductive variation and the egg size clutch size tradeoff within and among populations of Painted Turtles (Chrysemys picta bellii). Oecologia 99, 35-44.

Rowe, J. W. (1995). Hatchling size in the turtle Chrysemys picta bellii from Western Nebraska-Relationships to egg and maternal body size. Fournal of Herpetology 29, 73-79.

Runde, O. J. \& Barrett, R. T. (1981). Variations in egg size and incubation period of the Kittiwake Rissa tridactyla in Norway. Ornis Scandinavica 12, 80-86.

SAether, B.-E. (1990). Age-specific variation in reproductive performance of birds. In Current Ornithology, Volume 7 (ed. D. M. Power), pp. 251-283. Plenum Press, New York.

Sandercock, B. K., Lank, D. B. \& Cooke, F. (1999). Seasonal declines in the fecundity of arctic-breeding sandpipers: different tactics in two species with an invariant clutch size. Fournal of Avian Biology 30, 460-468.

Sandercock, B. K. \& Pedersen, H. C. (1994). The effect of renesting ability and nesting attempt on egg-size variation in Willow Ptarmigan. Canadian Fournal of Zoology 72, 2252-2255.

Sanz, J.J. \& Moreno, J. (1995). Experimentally induced clutch size enlargements affect reproductive success in Pied Flycatchers. Oecologia 103, 358-364.

Schluter, D. \& Gustafsson, L. (1993). Maternal inheritance of condition and clutch size in the Collared Flycatcher. Evolution 47, 658-667.

Scott, D. K. \& Birkhead, M. E. (1983). Resources and reproductive performance in Mute Swans Cygnus olor. Fournal of Zoology 200, 539-547.

Seigel, R. A. \& Ford, N. B. (1991). Phenotypic plasticity in the reproductive characteristics of an oviparous snake, Elaphe guttata - Implications for life-history studies. Herpetologica 47, 301-307.

Selman, R. G. \& Houston, D. C. (1996). The effect of prebreeding diet on reproductive output in Zebra Finches. Proceedings of the Royal Society of London Series B 263, 1585-1588.

Shanbhag, B. A., Radder, R. S. \& Saidapur, S. K. (2000). Maternal size determines clutch mass, whereas breeding timing influences clutch and egg sizes in the tropical lizard, Calotes versicolor (Agamidae). Copeia 2000, 1062-1067.

Simmons, R. E. (1994). Supplemental food alters egg size hierarchies within Harrier clutches. Oikos 71, 341-348.

Sinervo, B. (1990). The evolution of maternal investment in lizards - an experimental and comparative-analysis of egg size and its effects on offspring performance. Evolution 44, 279-294. 
Sinervo, B. \& Doughty, P. (1996). Interactive effects of offspring size and timing of reproduction on offspring reproduction: Experimental, maternal, and quantitative genetic aspects. Evolution 50, 1314-1327.

Sinervo, B., Doughty, P., Huey, R. B. \& Zamudio, K. (1992). Allometric engineering - a causal analysis of natural selection on offspring size. Science 258, 1927-1930.

Sinervo, B., Svensson, E. \& Comendant, T. (2000). Density cycles and an offspring quantity and quality game driven by natural selection. Nature 406, 985-988.

Slagsvold, T. \& LifJeld, J. T. (1988). Ultimate adjustment of clutch size to parental feeding capacity in a passerine bird. Ecology 69, 1918-1922.

Slagsvold, T. \& LifJeld, J. T. (1989). Constraints on hatching asynchrony and egg size in Pied Flycatchers. Fournal of Animal Ecology 58, 837-849.

Slagsvold, T. \& LifJeld, J. T. (1990). Influence of male and female quality on clutch size in Tits (Parus spp.). Ecology 71, 1258-1266.

Slagsvold, T., Sandvik, J., Rofstad, G., Lorentsen, Ö. \& Husby, M. (1984). On the adaptive value of intraclutch eggsize variation in birds. Auk 101, 685-697.

Smith, C. C. \& Fretwell, S. D. (1974). The optimal balance between size and number of offspring. American Naturalist $\mathbf{1 0 8 ,}$ 499-506.

Smith, H. G. \& Bruun, M. (1998). The effect of egg size and habitat on starling nestling growth and survival. Oecologia 115, 59-63.

Smith, H. G., Ohlsson, T. \& Wettermark, K.-J. (1995). Adaptive significance of egg size in the European Starling: experimental tests. Ecology 76, 1-7.

Smith, H. G., Отtosson, U. \& Ohlsson, T. (1993). Interclutch variation in egg mass among Starlings Sturnus vulgaris reflects female condition. Ornis Scandinavica 24, 311-316.

Sokal, R. R. \& Rohlf, F. J. (1995). Biometry. W.H. Freeman, New York.

Soler, M. \& Soler, J.J. (1996). Effects of experimental food provisioning on reproduction in the Jackdaw Corvus monedula, a semi-colonial species. Ibis 138, 377-383.

St. Clair, C. C. (1996). Multiple mechanisms of reversed hatching asynchrony in Rockhopper Penguins. Fournal of Animal Ecology 65, 485-494.

Steyermark, A. C. \& Spotila, J. R. (2001). Effects of maternal identity and incubation temperature on hatching and hatchling morphology in Snapping Turtles, Chelydra serpentina. Copeia 2001, 129-135.

Strausberger, B. M. (1998). Temporal patterns of host availability, Brown-Headed Cowbird brood parasitism, and parasite egg mass. Oecologia 116, 267-274.

Styrsky, J. D., Eckerle, K. P. \& Thompson, C. F. (1999). Fitness-related consequences of egg mass in nestling House Wrens. Proceedings of the Royal Society of London Series B 266, 1253-1258.

Su, G. S., Liljedahl, L. E. \& Gall, G. A. E. (1997). Genetic and environmental variation of female reproductive traits in Rainbow Trout (Oncorhynchus mykiss). Aquaculture 154, $115-124$.

Swennen, C. \& Meer, J. v. D. (1992). Variation in egg size of Common Eiders. Ardea 80, 363-373.

Sydeman, W. J. \& Eddy, J. O. (1995). Repeatability in laying date and its relationship to individual quality for Common Murres. Condor 97, 1048-1052.
Sydeman, W. J. \& Emslie, S. D. (1992). Effects of parental age on hatching asynchrony, egg size and third-chick disadvantage in Western Gulls. Auk 109, 242-248.

Tamate, T. \& Maekawa, T. (2000). Interpopulation variation in reproductive traits of female Masu Salmon, Oncorhynchus masou. Oikos 90, 209-218.

Teather, K. L., Boswell, J. \& Gray, M. A. (2000). Early lifehistory parameters of Japanese Medaka (Oryzias latipes). Copeia 2000, 813-818.

Thompson, P. S. \& Hale, W. G. (1991). Age-related reproductive variation in the Redshank Tringa totanus. Ornis Scandinavica 22, 353-359.

Tomasini, J. A., Collart, D. \& Quignard, J. P. (1996). Female reproductive biology of the Sand Smelt in brackish lagoons of southern France. Fournal of Fish Biology 49, 594-612.

Tucker, J. K. \& Janzen, F. J. (1998). Order of oviposition and egg size in the red-eared slider turtle (Trachemys scripta elegans). Canadian Fournal of Zoology 76, 377-380.

Tucker, J. K., Paukstis, G. L. \& Janzen, F. J. (1998). Annual and local variation in reproduction in the Red-eared Slider, Trachemys scripta elegans. Fournal of Herpetology 32, 515-526.

ViÑuela, J. (1997). Adaptation vs. constraint: intraclutch eggmass variation in birds. Fournal of Animal Ecology 66, 781-792.

Wallis, I. R., Henen, B. T. \& Nagy, K. A. (1999). Egg size and annual egg production by female Desert Tortoises (Gopherus agassizii): The importance of food abundance, body size, and date of egg shelling. Fournal of Herpetology 33, 394-408.

Weidinger, K. (1996). Egg variability and hatching success in the Cape Petrel Daption capense at Nelson Island, South Shetland Islands, Antarctica. Fournal of Zoology 239, 755-768.

Weimerskirch, H. (1990). The influence of age and experience on breeding performance of the Antarctic Fulmar, Fulmarus glacialoides. Fournal of Animal Ecology 59, 867-875.

Weimerskirch, H. (1992). Reproductive effort in long-lived birds: age-specific patterns of condition, reproduction and survival in the Wandering Albatross. Oikos 64, 464-473.

Wheelwright, N. T. \& Sahultz, C. B. (1994). Age and reproduction in Savannah Sparrows and Tree Swallows. Journal of Animal Ecology 63, 686-702.

Wiebe, K. L. \& Bortolotti, G. R. (1995). Egg size and clutch size in the reproductive investment of American Kestrels. Fournal of Zoology 237, 285-301.

Wiggins, D. A. (1990). Sources of variation in egg mass of Tree Swallows Tachycineta bicolor. Ornis Scandinavica 21, 157-160.

Williams, T. D. (1990). Growth and survival in Macaroni Penguin, Eudyptes chrysolophus, A- and B-chicks: do females maximise investment in the large B-egg? Oikos 59, 349-354.

Williams, T. D. (1994). Intraspecific variation in egg size and egg composition in birds : effects on offspring fitness. Biological Reviews 68, 35-59.

Williams, T. D. (1996a). Intra- and inter-individual variation in reproductive effort in captive-breeding Zebra Finches (Taeniopygia guttata). Canadian Fournal of Zoology 74, 85-91.

Williams, T. D. (1996b). Variation in reproductive effort in female Zebra Finches (Taeniopygia guttata) in relation to nutrient-specific dietary supplements during egg laying. Physiological Zoology 69, 1255-1275.

Williams, T. D. (1998). Avian Reproduction, Overview. In Encyclopedia of Reproduction, Volume 1 (eds. E. Knobil and J. D. Neill), pp. 325-336. Academic Press, San Diego.

Williams, T. D. (1999). Parental and first generation effects of exogenous $17 \beta$-estradiol on reproductive performance of 
female Zebra Finches (Taeniopygia guttata). Hormones and Behavior 35, 135-143.

Williams, T. D. (2000). Experimental (tamoxifen-induced) manipulation of female reproduction in Zebra Finches (Taeniopygia guttata). Physiological and Biochemical Zoology 73, $566-573$.

Williams, T. D. \& Cooch, E. G. (1996). Egg size, temperature and laying sequence: why do Snow Geese lay big eggs when it's cold?. Functional Ecology 10, 112-118.

Williams, T. D. \& Croxall, J. P. (1991). Annual variation in breeding biology of Macaroni Penguins, Eudyptes chrysolophus, at Bird Island, South Georgia. Fournal of Zoology 223, 189-202.

Williams, T. D., Jeffs, C., Murray, K. A. \& Choudhury, S. (1996). Intraclutch egg-size variation in the Barnacle Goose Branta leucopsis: an egg-removal experiment. Ibis 138, 499-505.
Williams, T. D., Lank, D. B. \& Cooke, F. (1993). Is intraclutch egg-size variation adaptive in the Lesser Snow Goose? Oikos 67, 250-256.

Williamson, I. \& Bull, C. M. (1995). Life-history variation in a population of the Australian frog Ranidella signifera - Seasonal-changes in clutch parameters. Copeia 1995, 105-113.

Winkler, D. W. \& Allen, P. E. (1995). Effects of handicapping on female condition and reproduction in Tree Swallows (Tachycineta bicolor). Auk 112, 737-747.

Wootton, R. J. (1973). The effect of size of food ration on egg production in the female Three-Spined Stickleback, Gasterosteus aculeatus L. Fournal of Fish Biology 5, 89-96.

ZACH, R. (1982). Hatching asynchrony, egg size, growth, and fledging in Tree Swallows. Auk 99, 695-700. 